University of California, Hastings College of the Law UC Hastings Scholarship Repository

Faculty Scholarship

1982

\title{
Suing Foreign Sovereigns: A Procedural Compass
}

Mary Kay Kane

UC Hastings College of the Law, kanem@uchastings.edu

Follow this and additional works at: http://repository.uchastings.edu/faculty_scholarship

Part of the Jurisdiction Commons

\section{Recommended Citation}

Mary Kay Kane, Suing Foreign Sovereigns: A Procedural Compass, 34 Stan. L. Rev. 385 (1982).

Available at: http://repository.uchastings.edu/faculty_scholarship/300

This Article is brought to you for free and open access by UC Hastings Scholarship Repository. It has been accepted for inclusion in Faculty Scholarship by an authorized administrator of UC Hastings Scholarship Repository. For more information, please contact marcusc@uchastings.edu. 


\section{Faculty Publications \\ UC Hastings College of the Law Library}

Author: Mary Kay Kane

Source: $\quad$ Stanford Law Review

Citation: 34 Stan. L. Rev. 385 (1982).

Title: $\quad$ Suing Foreign Sovereigns: A Procedural Compass

Originally published in STANFORD LAW REVIEW. This article is reprinted with permission from STANFORD LAW REVIEW and Stanford Law School. 


\title{
Suing Foreign Sovereigns: A Procedural Compass
}

\author{
Mary Kay Kane*
}

Since the Foreign Sovereign Immunities $\mathrm{Act}^{1}$ is intended to provide a comprehensive scheme for actions against foreign sovereigns, it deals with both substantive and procedural issues pertinent to those suits. Substantively, the statute defines what entities may be treated as foreign states." It also codifies the doctrine of "restrictive immunity,"3 which recognizes immunity only for those acts that are public in character, ${ }^{4}$ and sets forth criteria to distinguish public from pri-

* B.A. 1968, J.D. 1971, University of Michigan. Professor of Law, University of California, Hastings College of the Law.

1. Foreign Sovereign Immunities Act of 1976, Pub. L. No. 94-583, 90 Stat. 2891 (codified at 28 U.S.C. $\S \S 1330,1332(\mathrm{a})(2),(4), 1391($ ), 1441 (d), 1602-1611 (1976) [hereinafter cited as the Act]. The Act went into effect on January 19, 1977.

2. See 28 U.S.C. $\$ 1603(a)$-(b) (1976). The Act specifically includes in its definition of a foreign state the political subdivisions of foreign states and agencies or instrumentalities of foreign states. Id. $\S 1603$ (a). It then defines agency or instrumentality as any entity which is a separate legal person, an organ of a foreign state, or whose major ownership interest is held by a foreign state, and is not otherwise a citizen of the United States or created under the laws of some third country. Id. $\S 1603$ (b). These definitions put to rest some confusion that existed under prior law concerning whether political subdivisions should be entitled to claim sovereign immunity and how to treat separate entities that were controlled by, or in some other way closely related to, foreign governments. See Annot., 25 A.L.R.3d 332, 339-42 (1969). Unless otherwise indicated, throughout this article references to foreign states should be read to include political subdivisions and agencies; I leave to other writers the task of defining those terms further. See Kahale \& Vega, Immunity and Jurisdiction: Toward a Uniform Body of Law in Actions Against Foreign Stales, 18 Colum. J. TRANSNAT'L L. 211, 226-29 (1979).

3. In 1952 the State Department adopted the principle of restrictive sovereign immunity. See Letter from Jack B. Tate, Acting Legal Advisor of the Dep't of State, to Philip B. Perlman, Acting Attorney General (May 19, 1952), reprinted in 26 DEP'T ST. BuLL. 984 (1952). Operating under this principle until the enactment of the Act in 1976, courts allowed the defending foreign state either to raise sovereign immunity as a defense in pending litigation or to petition the State Department to rule that the acts involved were public in character and therefore immune. The State Department then would make a formal suggestion of immunity to the court which, in practice, was binding. For a discussion of the treatment of foreign sovereign immunity prior to the Act, see Von Mehren, The Foretgn Sovereign Immunities Act of 1976, 17 Colum. J. Transnat'l L. 33, 39-43 (1978); Note, The Foreign Sovereign Immunilies Acl of 1976: Giving the Plaintiff His Day in Court, 46 Fordham L. Rev. 543, 544-50 (1977). See generally Annot., supra note 2.

4. Although the courts had been applying the restrictive immunity concept prior to 
vate acts. ${ }^{5}$ Procedurally, it sets standards for both subject matter and personal jurisdiction over foreign governments, ${ }^{6}$ establishes procedures for service of process, ${ }^{7}$ and authorizes the execution of judgments against foreign states. ${ }^{8}$

All the procedural standards derive from a single interlocking standard for assessing the propriety of an action against a foreign sovereign. The federal district courts have subject matter jurisdiction $^{9}$ whenever the defendant is a foreign state as defined in the Act $^{10}$ and does not fall within one of the Act's exceptions to immunity. ${ }^{11}$ Personal jurisdiction ${ }^{12}$ exists whenever there is subject matter jurisdiction and proper service is made. ${ }^{13}$

The guidance provided by the statute as to how this scheme should operate is far from clear, as can be gathered from a simple reading of the statute and as is proven by the ample confusion that has attended judicial efforts to cope with this new creature in the short five years it has been in effect. At least some of the confusion may be explained by the approach taken in the statute itself. ${ }^{14}$ The Act blends into a purportedly single standard of "jurisdiction" both

1976, there was no agreement as to how to distinguish between acts that were public in character (jure imperii), and so immune, and acts that were commercial (jure gestionis), for which immunity was not available. Some courts looked to the nature of the transaction; some attempted to determine the purpose of the activity; and some simply deferred unquestioningly to the State Department's recommendations on the question. See Note, Sovereign Immunity of States Engaged in Commercial Activities, 65 Colum. L. Rev. 1086, 1095-98 (1965). See generally Annot., supra note 2. The Act adopts the "nature of the transaction" test, 28 U.S.C. § 1603(d) (1976), resolving any doubts concerning what standard to use. But problems in applying that standard still remain. See Von Mehren, supra note 3, at 52.

5. 28 U.S.C. $\S \S 1604-1605$ (1976).

6. Id. $\S \S 1330,1332,1441(\mathrm{~d})$.

7. Id. $\S 1608$.

8. Id. $\S \S 1609-1611$.

9. Id. $\S 1330(\mathrm{a})$.

10. Id. $\S 1603(\mathrm{a})$.

11. Id. $\S \S 1330(\mathrm{a}), 1605-1607$.

12. Id. $\S 1330(\mathrm{~b})$.

13. Id. $\S 1608$.

14. For example, $\S 1605$ (a)(1) of the Act provides for the judicial power of either federal or state courts over claims against a foreign sovereign that has "waived its immunity either explicitly or by implication." By blending into jurisdictional provisions unrelated concerns involving immunity, the legislature appears to be authorizing the defendant state to consent to jurisdiction. Yet it is familiar law that federal subject matter jurisdiction cannot be waived by a party's failure to object, and the court must inquire into jurisdiction sua sponie, even when the parties expressly agree to litigate in federal court. See 5 G. WRIGHT \& A. MILLER, Federal Practice and Procedure $\$ 1393$ (1969 \& Supp. 1981). But it is only superficially true that jurisdiction under the Act seems to be conferred by agreement or by waiver. The power of the court is created by the Act and the Act also expands the obligation of the sovereign to submit to that power, but a residue of immunity still exists. An agreement not to 
substantive declarations about immunity and some quite varied functional tests about procedural considerations for litigation. This interdependence of concepts that we otherwise insist on keeping separate and distinct has, predictably, caused problems that need never have arisen.

Although it may seem artificial in light of the statutory approach just described, the Act is best understood in a more traditional manner, by considering the procedural aspects separately from questions of immunity. ${ }^{15}$ While the reader may conclude that only Congress can solve these problems--by rewriting the Act-this article will proceed on the premise that the congressional objectives must and can be reached through the existing words of the statute. Turning strange things into familiar ones makes it easier to recognize the legislature's objectives—objectives that are clearly stated, even if the means to achieve them are not. The goal of this inquiry is to provide a procedural guide for suits properly brought under the statute, rather than to decide which suits those should be.

Part I of the article examines the procedure for selecting the court in which to file an action against a foreign entity, and discusses the standards for determining subject matter jurisdiction, personal jurisdiction, and venue. Part II considers the special procedures applicable in proceedings against foreign sovereigns, ${ }^{16}$ as well as the proper manner in which to raise immunity objections under the statute-an issue on which the statute is silent and about which there seems to be some confusion. This Part also considers who bears the burden of proving immunity and how that burden may be satisfied. Finally, this Part explores whether a jury trial may be demanded in an action against a foreign government, despite statutory language to the contrary.

raise immunity claims merely reduces the residue still further. See Reale Int'l, Inc. v. Federal Republic of Nigeria, 647 F.2d 330 (2d Cir. 1981).

15. See, e.g. , Harris v. VAO Intourist, Moscow, 481 F. Supp. 1056, 1062 (E.D.N.Y. 1979) ("[T] $]$ he Immunities Act incorporates in the same provisions answers to three issues: ( $\mathrm{t}$ ) when to grant immunity . . . ; (2) what is the basis for long-arm in personam jurisdiction . . .; and (3) how great is the scope of subject matter jurisdiction. The effect of this construction is to conceal distinctions that need to be drawn in careful analysis.").

16. This inquiry will not entail any study of the postjudgment attachment and execution provisions of the statute. Although they are clearly important and may produce many interesting problems and questions, this article focuses on the procedural rules governing actions against foreign sovereigns until a judgment is obtained. Postjudgment remedies are left for later explorations. For the views of other commentators on this subject, see Del Bianco, Execution and Attachment Under the Foreign Sovereign Immunities Act of 1976, 5 YALE STUD. WORLD PUB. ORD. 109 (1978); Von Mehren, supra note 3. 


\section{Selecting a Proper Court}

As in all civil litigation, the first concern when filing a lawsuit against a foreign sovereign is determining which courts have subject matter and personal jurisdiction and venue.

\section{A. Subject Matter Jurisdiction}

The Act grants original jurisdiction to the federal district courts in any nonjury ${ }^{17}$ civil action against a foreign state that is not entitled to immunity. ${ }^{18}$ The jurisdiction of the federal district courts is concurrent with that of the state courts, ${ }^{19}$ although the foreign state is entitled to remove the action to the federal court if it so desires. ${ }^{20}$

Although these provisions appear relatively straightforward, they raise several interesting questions. First, may alien plaintiffs sue foreign states under the Act? Second, is the Act intended to provide the exclusive basis for jurisdiction in suits against foreign sovereigns? Third, what procedures control removal? This section considers each of these issues.

\section{Suits by alien plaintiffs.}

The Act confers federal subject matter jurisdiction over actions against a foreign state without reference to the plaintiff's citizen-

17. On jury trial in an action against a foreign sovereign, see text accompanying notes 187-201 infra.

18. Prior to 1976, federal subject matter jurisdiction in actions against foreign sovereigns rested on the diversity statute, which provided for jurisdiction in actions involving more than $\$ 10,000$ that were between "citizens of a State, and foreign states or citizens or subjects thereof." 28 U.S.C. § 1332(a)(2) (1976). Congress recognized that this jurisdictional base was superfluous when it added $\S 1330$, and thus it amended $\S 1332$ (a)(2) to refer only to actions between "citizens of a State and citizens or subjects of a foreign state." See H.R. REP. No. 1487, 94th Cong., 2d Sess. 14, reprinted in [1976] 5 U.S. CODE CONG. \& AD. NEws 6604, 6613 [hereinafter cited as HOUSE REPORT]. The Act also amended the diversity statute to provide for federal subject matter jurisdiction in suits involving more than $\$ 10,000$ that were brought by foreign sovereigns against "citizens of a State or of different States." 28 U.S.C. $\S 1332(a)(4)$ (1976). Other sections of the Act specify the definition of foreign state and the scope of immunity. Id. $\S \S 1603(\mathrm{a})-(\mathrm{b}), 1604-1607$.

19. The legislative history contains no clear statement why Congress decided to provide for concurrent rather than exclusive federal court jurisdiction. Congress appears to have assumed that most cases would be filed in federal courts and therefore sought to afford easy access to them. Perhaps because litigants could file suit against foreign states in state or federal court prior to the Act, Congress saw no reason to alter that practice inasmuch as removal could allay fears of local prejudice or nonuniform standards. See 28 U.S.C. $\$ 1441$ (d) (1976); House REPORT, supra note 18, at 13, reprinted in [1976] 5 U.S. CODE CONG. \& AD. News $6604,6611$.

20. For a discussion of removal, see text accompanying notes 48-62 infra. 
ship. ${ }^{21}$ Taken literally, this would authorize suits by alien plaintiffs in federal court. But allowing such suits would in some ways be a departure from past practice. ${ }^{22}$ The general diversity statute does not provide for actions between aliens, ${ }^{23}$ and the judicial power clause of the Constitution ${ }^{24}$ makes no reference to actions solely between citizens of foreign states. ${ }^{25}$

Interpreting the Act to confer federal jurisdiction over these actions has been challenged on two grounds. The first is that the Act was not intended to afford a federal forum for the claims of aliens. ${ }^{26}$ The second challenge is that federal jurisdiction over actions brought by aliens against foreign states is not authorized by article III of the Constitution, and is therefore beyond the power of Congress to confer. ${ }^{27}$

The evidence of congressional intent on the first question is inconclusive. The Act's own declaration of purpose refers to protecting "both foreign states and litigants" in United States courts, ${ }^{28}$ and the House Report on the bill expresses a desire to provide guidelines for "parties" maintaining a lawsuit against a foreign state. ${ }^{29}$ But no-

21. 28 U.S.C. $\S 1330$ (1976).

22. A Second Circuit decision in which suit was filed premised on diversity prior to the effective date of the Act suggested this problem, but avoided resolving it. When the defendant challenged on the ground that both the plaintiff, a Venezuelan governmental entity, and one of the defendants, a Swiss corporation, were aliens, the plaintiff argued that the court should apply the Act retroactively to confer jurisdiction. The court rejected this argument since it found no congressional intent to affect pending lawsuits. Corporacion Venezolana de Fomento v. Vintero Sales Corp., 629 F.2d 786 (2d Cir. 1980), cert. denied, 101 S. Ct. 863 (1981).

23. See C. Wright, LaW OF Federal Courts $\S 24$, at 93 (3d ed. 1976).

24. U.S. CONST. art. III, § 2.

25. See Hodgson \& Thompson v. Bowerbank, 9 U.S. (5 Cranch) 303 (1809).

26. One might argue that United States courts should not be clogged with disputes between foreign parties in which the courts have no interest, and that they should not provide a forum for alien plaintiffs who could not sue in their own courts. This concern, though facially valid, is not compelling. To come within one of the exceptions to immunity listed in the statute, see 28 U.S.C. $\S \S 1604-1607$ (1976), the transaction on which the suit is based necessarily will have had some connection with the United States, so that it is unlikely that totally foreign disputes will clog our courts. And, to the extent that a suit has only a tenuous connection with the United States, the court may invoke the doctrine of forum non conveniens to dismiss the action, thereby further protecting itself from unwanted litigation. See text accompanying notes $134-42$ infra.

27. Congressional authority for providing jurisdiction in suits against foreign sovereigns might be found in article I. Under the powers granted therein, Congress can regulate commerce with foreign nations, U.S. CoNST. art. I, $\S 8, \mathrm{cl} .3$, and may define offenses against the "Law of Nations," id., cl. 10. As part of the exercise of those powers, Congress might grant the federal courts article I jurisdiction to hear cases under the Act.

28. 28 U.S.C. § 1602 (1976).

29. HOUSE REPORT, supra note 18, at 6 , reprinted in [1976] 5 U.S. CODE CONG. \& AD. News 6604, 6604. 
where is there any indication that the Congress specifically considered whether the new jurisdiction statute would be available to foreign plaintiffs. Most likely, the question simply was not raised. While the legislative history may be confusing ${ }^{30}$ the statute itself is quite clear. It grants federal jurisdiction for actions against foreign entities regardless of the identity of the plaintiff and provides for the removal of suits brought against foreign states in state courts. ${ }^{31}$

Thus, although allowing foreign plaintiffs to sue other than in tort departs from prior practice, the unequivocal wording of the Act, plus the absence of legislative history suggesting any limit on the nationality of parties able to benefit from the Act, seem to make them eligible. Verlinden B.V. v. Central Bank of Nigeria, the only case on point, so held. ${ }^{32}$

The constitutional issue raised by allowing alien plaintiffs to sue is whether these are cases "arising under . . . the Laws of the United States." 33 The argument supporting jurisdiction on this clause may be based on two different premises. The first is that the statute provides some substantive rules of decision or attempts in some way to regulate conduct, and thus suits invoking the Act necessarily meet the "arising under" criteria. The second argument is that there is a sufficient national or federal interest in cases against foreign sovereigns to compel use of a federal rule of decision rather than state law.

The Second Circuit recently addressed both of these questions and ruled that jurisdiction could not be asserted constitutionally. ${ }^{34}$ The court's conclusion that there was not a sufficient federal interest simply because of an asserted need for a uniform standard under

30. See Jurisdiction of U.S. Courts in Suits Against Foreign States: Hearings on H.R. 11315 Before the Subcomm. on Administrative Law and Governmental Relalions of the House Comm. on the Judiciary, 94th Cong., 2d Sess. 24 (1976) (statement of Monroe Leigh) [hereinafter cited as 1976 Hearings]; see also id. at 31 (statement of Bruno Ristau).

31. See 28 U.S.C. $\$ \S 1330,1441$ (d) (1976).

32. 647 F.2d 320, 324 (2d Cir. 1981); see also Filartiga v. Peña-Irala, 630 F.2d 876 (2d Cir. 1980) (allowing a suit by an alien plaintiff against a foreign government under the Alien Tort Statute, 28 U.S.C. § 1350 (1976)); Comment, Torture as a Tort in Violation of International Law: Filartiga v. Peña-Irala, 33 Stan. L. Rev. 353 (1981).

33. U.S. ConsT. art. III, § 2. 28 U.S.C.A. § 1331 (West Supp. 1981) authorizes general federal question jurisdiction in all suits "arising under the . . laws . . of the United States," but that provision has been limited to actions in which a well-pleaded complaint reveals the federal question to be decided. See Louisville \& Nashville R.R. v. Mottley, 211 U.S. 149 (1908). The Act's sovereign immunity question presents a clear federal issue, but one raised properly by defense, not on the face of the complaint. See Verlinden B.V.v. Central Bank of Nigeria, 647 F.2d 320, 326-27 (2d Cir. 1981). Thus, the question presented is whether the "arising under" language in U.S. CONST. art. III, $\S 2$ is sufficiently broader than the statute to allow these suits to be brought.

34. Verlinden B.V. v. Central Bank of Nigeria, 647 F.2d 320 (2d Cir. 1981). 
which foreign states might be sued ${ }^{35}$ seems sound, although a sufficient federal interest might be found depending on the underlying facts in a given case. ${ }^{36}$ However, its conclusion that the Act does not provide any substantive rules of decision is unduly narrow.

Any federal complaint must invoke section 1606 of the Act, which defines the extent of liability of a foreign state. That section declares that the foreign state is liable to "the same extent as a private individual under like circumstances," but qualifies the principle by precluding the recovery of punitive damages and by substituting a compensatory remedy for wrongful death if the law of the place where the action or omission occurred employs a punițive measurement. $^{37}$ Suits against foreign sovereigns now, if not before, arise under federal law because the Act establishes a liability standard for them. That standard incorporates the law of the place where the "action or omission" occurred, and applies certain modifications to it. In cases against foreign governments in state courts, the state court would be obliged, like the federal court, to resort to the Act to determine the liability standard to be applied in suits against foreign states. ${ }^{38}$

\section{Jurisdiction based outside of section 1330.}

The question whether Congress intended section 1330 to provide the only proper jurisdictional base for suits against foreign governments is important because section 1330 contains procedural restrictions that do not normally apply to other civil actions in the federal courts. It allows jurisdiction only for nonjury actions, ${ }^{39}$ and authorizes only in personam jurisdiction, precluding the prejudgment attachment of defendant's property. ${ }^{40}$

Litigants already have tried to assert alternate bases for jurisdiction, alleging jurisdiction based on the diversity statute as suits be-

35. Id. at 329.

36. See, e.g., Mashayekhi v. Iran, 515 F. Supp. 41 (D.D.C. 1981) (Iranian seeking compensation from Iran and Iranian national radio and television for work done in United States).

37. 28 U.S.C. $§ 1606$ (1976).

38. Deliberate adoption of state law (whether foreign or domestic) is just as much a "law of the United States" as is substitution of a congressionally preferred damages standard. This is unlike the principles prevailing in Erie R.R. v. Tompkins, 304 U.S. 64 (1938), where state law controlled because Congress could not act, or had not acted. Here both the liability and damages rules are those that Congress deliberately specified.

39. See 28 U.S.C. $\$ \S 1330(a), 1441$ (d) (1976); text accompanying notes 187-201 infra.

40. See text accompanying notes 116-26 infra. 
tween "citizens of a state and citizens or subjects of a foreign state,"41 or under the general federal question statute, as for example, an action by a longshoreman seeking damages under the federal longshoremen's compensation act from a foreign government for injuries sustained when aboard a ship owned by that government. ${ }^{42}$ In each of these instances the litigants clearly met the standards in the alternate jurisdictional statutes. ${ }^{43}$

The courts disagree as to whether section 1330 was intended to be the exclusive source of jurisdiction for cases brought under the Act. Those finding exclusivity argue that Congress meant the procedures set forth in the statute to govern in all suits against foreign sovereigns and that it therefore is necessary to limit jurisdiction to section $1330 .{ }^{44}$ Courts that have allowed suits outside section 1330 have declined to preclude jurisdiction in the absence of a more explicit command from Congress. ${ }^{45}$

The decisions of courts on both sides of the issue reveal the confusion that arises from the blend of substantive and procedural criteria in the Act. ${ }^{46}$ Even if Congress intended to specify the exclusive procedures to be used in suits against foreign governments, section 1330 need not provide the sole basis for federal subject matter jurisdiction. Questions of subject matter jurisdiction address the issue of whether the federal court is competent to handle certain controversies. Which procedures must be used in actions against foreign sovereigns

41. 28 U.S.C. § 1332(a)(2) (1976) (amended 1976, see note 18 supra); see, e.g., Geveke \& Co. Int'l v. Kompania di Awa i Elektrisidat di Korsou N.V., 482 F. Supp. 660 (S.D.N.Y. 1979) (refusing to grant jurisdiction outside of the Act).

42. The federal question statute, 28 U.S.C.A. $\S 1331$ (West Supp. 1981), thus might be applied to the Longshoremen's and Harbor Workers' Compensation Act, 33 U.S.C. $\$ \S 901-950$ (1976); see, e.g., Rex v. Cia. Pervana de Vapores, S.A., 493 F. Supp. 459 (E.D. Pa. 1980).

43. In other types of litigation in which more than one jurisdictional statute may be applicable, the plaintiff may choose which statute to invoke, thereby avoiding some requirements. For example, compare interpleader actions under FED. R. GIV. P. 22 with statutory interpleader actions under 28 U.S.C. $\$ 1335$ (1976). See C. WRIGHT, supra note $23, \S 74$.

44. For decisions finding $\S 1330$ to be the exclusive means of obtaining federal subject matter jurisdiction over foreign sovereigns, see, e.g., Ruggiero v. Compania Peruana de Vapores "Inca Capac Yupanqui," 639 F.2d 872 (2d Cir. 1981); Jones v. Shipping Corp. of India, 491 F. Supp. 1260 (E.D. Va. 1980); Williams v. Shipping Corp. of India, 489 F. Supp. 526 (E.D. Va. 1980); Geveke \& Co. Int'l v. Kompania di Awa i Elektrisidat di Korsou N.V., 482 F. Supp. 660 (S.D.N.Y. 1979).

45. For decisions allowing jurisdiction to be based outside of $\S 1330$, see, e.g., Rex v. Cia. Pervana de Vapores, S.A., 493 F. Supp. 459 (E.D. Pa. 1980); Houston v. Murmansk Shipping Co., 87 F.R.D. 71 (D. Md. 1980); Lonon v. Companhia de Navegacao Lloyd Basileiro, 85 F.R.D. 71 (E.D. Pa. 1979); Icenogle v. Olympic Airways, S.A., 82 F.R.D. 36 (D.D.C. 1979). 46. See notes $14-15$ supra and accompanying text. 
is a separate problem; it does not speak to the federal courts' competence to decide these actions. Thus, a plaintiff suing a foreign government may attempt to claim federal jurisdiction under any statutory base for which the requirements are met. Whether the procedures applicable to that suit are limited to those set forth in the Act depends on whether they were meant to be exclusive; if so, they should apply regardless of the jurisdictional base of the lawsuit.

Defining the problem as one concerning whether exclusive procedures were intended may lead to the same conclusion as when the problem is treated as an exclusive jurisdiction problem. Nonetheless, the process by which that conclusion is reached will be much more straightforward, with less likelihood of confused or erroneous rulings resulting from a misplaced reliance on jurisdictional considerations. ${ }^{47}$ In addition, identifying the question as one concerning the applicability of procedures eliminates one more preliminary inquiry in suits against foreign governments: Courts may postpone decisions regarding the exclusivity of certain procedures until the applicability of a given procedure is questioned.

\section{Removal jurisdiction.}

A foreign state defendant not wanting to submit to the jurisdiction of a state court has an unqualified right to remove such an action to the federal district court in the district and division where the state action is pending. ${ }^{48}$ Two issues involving the Act's removal provisions have arisen. First, there is the question of whether the statute authorizes the removal of claims against nonstate co-defendants in the suit. ${ }^{49}$ Second, there has been some question concerning the timing restrictions that apply to removal by foreign sovereigns.

The foreign state defendant in a multiparty suit clearly may re-

47. For an example of the confused and complex reasoning that comes from treating the question of jury trial rights as dependent on the statutory basis for jurisdiction, see Rex v. Cia. Pervana de Vapores, S.A., 493 F. Supp. 459 (E.D. Pa. 1980).

48. 28 U.S.C. $\S 1441$ (d) (1976). The sole criterion for removal is that the court must find that the defendant is a foreign state under the Act. See note 2 supra.

49. Notably, if 28 U.S.C. $\$ 1441$ (d) (1976) were construed to preciude removal of the entire action by the foreign state defendant, removal might be accomplished under id. $\S 1441(c)$, which authorizes removal "[w]henever a separate and independent claim or cause of action, which would be removable if sued upon alone, is joined with one or more otherwise non-removable claims or causes of action." But removal would be less certain than under $\S 1441$ (d) because it would depend on finding that the additional claims not against the foreign state were "separate and independent" and would allow the court to remand the other claims to state court. 
move the entire action, ${ }^{50}$ and the court can retain jurisdiction over the claims of foreign nonstate defendants even if those claims could not have been brought independently in the federal courts. This conclusion is derived, first, from the power of Congress to authorize jurisdiction based on only minimal diversity, ${ }^{51}$ and second, from the broad scope of the "necessary and proper" clause of the Constitution, ${ }^{52}$ which allows Congress to provide for jurisdiction beyond the strict limits of article III. ${ }^{53}$ In the Act, Congress not only attempted to avoid the fragmentation of litigation; but also made law potentially affecting relations with foreign governments-an issue clearly within its constitutional domain. In addition, one court has suggested that allowing removal of the entire action.would be constitutional as long as pendent jurisdiction could properly be asserted over the additional claims and parties. ${ }^{54}$

50. Focusing on the language of the Act, the court in Arango v. Guzman Travel Advisors Corp., 621 F.2d 1371, 1376 (5th Cir. 1980), noted that the Act referred to the removal of "[a]ny civil action," 28 U.S.C. $\$ 1441$ (d) (1976), not the removal of claims, and that courts had interpreted similar language in a statute authorizing removal by federal officers sued in state courts, id. $\$ 1442(\mathrm{a})(1)$, to include all the claims then pending. Further, the legislative history suggests that Congress wanted to give foreign states clear authority to remove regardless of the presence of multiple defendants, 621 F.2d at 1375, even when some of the defendants might prefer to remain in state court. Congress preferred this result "[i]n view of the potential sensitivity of actions against foreign states and the importance of developing a uniform body of law in this area." House REPORT, supra note 18, at 32, reprinted in [1976] 5 U.S. CODE CoNG. \& AD. News 6604,6631 . General notions of judicial economy also support removal of the other claims in order to avoid repetitive or multiple lawsuits in the state and federal courts.

51. E.g., 28 U.S.C. $\S 1335($ a)(1) (1976) (interpleader).

52. U.S. ConsT. art. I, $\S 8$, cl. 18.

53. This question arose involving the more general removal provision, 28 U.S.C. $\S 1441$ (c) (1976), which authorizes removal of an entire action when the court finds that a separate and independent claim "which would be removable if sued upon alone, is joined with one or more otherwise non-removable claims." A party challenged that provision on the ground that it effectively allowed suits in the federal courts that did not meet the complete diversity requirement. See Twentieth Century-Fox Film Corp. v. Taylor, 239 F. Supp. 913 (S.D.N.Y. 1965). The court based its decision upholding the statute on the powers noted in text accompanying notes $51-52$ supra. This same rationale would uphold the constitutionality of $\S 1441(d)$.

54. Arango v. Guzman Travel Advisors Corp., 621 F.2d 1371, 1377 n.7 (5th Cir. 1980). If this pendent jurisdiction analysis were to apply generally, the only limitations on the removal of claims against additional defendants would be the considerations whether all the claims arise out of a common nucleus of operative fact, whether it will be judicially economical to try all the claims together, and whether Congress "has addressed itself to the party as to whom jurisdiction pendent to the principal claim is sought." Aldinger v. Howard, 427 U.S. 1, 16 (1976) (emphasis in original). The Arango court found that Congress intended to allow the removal of pendent parties. $621 \mathrm{~F} .2 \mathrm{~d}$ at 1377 . Since in most cases in which the plaintiff is suing multiple defendants, the claims, though separate, all will arise out of a single transaction or series of related occurrences, FED. R. GIV. P. 20(a), this standard easily should be 
Removal is governed by the same procedures that apply to other actions, ${ }^{55}$ except with respect to the time the foreign state has to remove the action or waive its rights of removal. ${ }^{56}$ Normally, a defendant loses the right to remove if the petition is not filed within thirty days after receipt of the summons or complaint. ${ }^{57}$ The removal provision in the Act, however, specifically allows the time limitation to be enlarged "at any time for cause shown."

Although a "for cause shown" standard may seem quite vague, the phrase takes substantial content from other contexts. For example, a defendant may move to set aside the entry of a.default "for good cause shown." In that context, four elements support a showing of good cause: (1) there is some excuse for allowing the default; (2) a meritorious defense to the action exists; (3) the plaintiff will not be seriously prejudiced if the default is set aside; and (4) the motion was made promptly upon learning of the default entry. ${ }^{60} \mathrm{Al}$ though not all of these concerns are relevant to a late attempt to remove, ${ }^{61}$ the above list suggests that courts will weigh the reasons for the delay against the potential prejudice to the plaintiff if removal is allowed. An additional important factor affecting this balancing process is the expressed desire of Congress to allow removal freely in order to assure foreign states access to a federal forum. ${ }^{62}$

satisfied. Thus, as a practical matter no serious barrier to the removal of the entire action exists under either analysis.

55. 28 U.S.C. § 1446(b) (1976).

56. Although the removal provision does not speak to the question of what, if any, acts on the part of the defendant in the state court proceeding constitute a waiver of rights of removal, it is quite clear that waiver will occur only if the foreign state fails to move in a timely fashion and cannot show adequate cause to enlarge the normal period. It is well established in other removal contexts that the defendant's conduct prior to removal cannot be used to establish waiver: The right to remove is absolute as long as a timely motion is filed. See 14 C. Wright, A. Miller \& E. CoOper, Federal Practice ANd Procedure § 3732, at 731 (1976). And since Congress, by allowing the extension of time limits, treats foreign state defendants even more generously than it does other defendants, it seems inconceivable that the former would have implicitly waived that right by some other conduct. Indeed, some authorities have argued that the absence of any provision in the Act stipulating how and when to waive the right to remove should be taken as precluding the waiver of those rights even by contract. See id. §3729, at 170-71 (Supp. 1980).

57. 28 U.S.C. § 1446(b) (1976).

58. Id. $\S 1441(\mathrm{~d})$.

59. FED. R. CIV. P. 55(c).

60. See 10 C. WRIGHT \& A. MilleR, supra note 14, § 2692, at 301-02 (1973).

61. Whether the foreign state has a meritorious defense to the action seems irrelevant to the question whether the action may be tried in federal, rather than state court.

62. See note 50 supra. The only reported case applying the "for cause shown" standard in the removal statute seems to support the above analysis. Gray v. Permanent Mission of People's Republic of Congo to United Nations, 443 F. Supp. 816 (S.D.N.Y. 1978), affd mem., 
Thus, a foreign state should be able to invoke removal jurisdiction for any action, even if other nongovernmental defendants also are present. Further, a court should not impose rigid time constraints on a foreign state desiring to remove, as long as there is good cause for the delay. Rather, the court should base its disposition of an untimely petition to remove on a balance of the interests of the parties and the policy of the Act to provide easy access to the federal courts for foreign government defendants.

\section{B. Personal Jurisdiction}

To American lawyers and judges, whether the Republic of France can be sued is very different from the question of where France may be sued. We answer the first inquiry by examining whether France enjoys immunity in American courts. We answer the second by asking whether France has engaged in acts or conduct which warrant summoning it before the courts of some jurisdiction.

But does that latter question even exist under the Act? No court has found any intrinsic limit on the worldwide service of process by federal courts if congressional intent on this point is clear. Under this approach, compliance with the statute's service provision alone could suffice to establish personal jurisdiction. ${ }^{63}$

Although the Act does not explicitly consider the propriety of this approach, both its legislative history ${ }^{64}$ and the uniform holding of the

580 F.2d 1044 (2d Gir. 1978). The court allowed removal even though the action was seven months old and judgment had been entered. Id. at 819 . The cause shown to support allowing this untimely removal was that the defendant never had received proper service of the original complaint, and thus lacked adequate notice of the proceedings in order to remove earlier. For a discussion of proper methods of service of process, see text accompanying notes $68-93$ infra.

63. The reason the courts must find that the application of personal jurisdiction does not violate the due process clause, U.S. CoNST. amend. V, is that only judgments obtained in keeping with it will be fully enforceable throughout the United States under the full faith and credit clause, id. art. IV, $\S 1$. See Pennoyer v. Neff, 95 U.S. 714, 728, 732-33 (1878). If a judgment against a foreign sovereign must be enforced outside the United States, then only notions of comity control. See A. EHRENZWEIG, Conflict of LAWS $\S 46$ (1959). Many civil law countries have authorized personal jurisdiction on bases far less compelling than minimum contacts, allowing jurisdiction solely because of the nationality of the plaintiff or presence of the defendant, although these more extravagant forms of jurisdiction also seem to be disappearing. See Riesenfeld, Shaffer v. Heilner: Holding, Implications, Forebodings, 30 Hastings L.J. 1 183, 1201-02 (1979). Nonetheless, at least insofar as personal jurisdiction concerns are centered on the need to render an enforceable judgment, a United States judgment entered against a defendant who lacks the requisite minimum contacts with the United States may still be enforceable abroad as a perfectly proper judgment.

64. See HOUSE REPORT, supra note 18, at 13, reprinted in [1976] 5 U.S. CODE CONG. \& AD. NEws 6604, 6612 ("Significantly, each of the immunity provisions in the bill, sections 
decisions thus far ${ }^{65}$ prevent this conclusion. Thus, when filing suit against a foreign government it is necessary to consider not only whether the service requirements are met, but also whether the assertion of personal jurisdiction would be consistent with the constitutional due process standard set out in International Shoe Co. $v$. Washington ${ }^{66}$ - that the defendant has sufficient minimum contacts with the forum so that notions of fair play and substantial justice would not be offended if jurisdiction were asserted. ${ }^{67}$

The Act does depart from traditional precepts of personal jurisdiction, however, in its treatment of quasi in rem jurisdiction and prejudgment attachments. This section will conclude with a discussion of those provisions.

\section{Service of process.}

As indicated earlier, the Act authorizes personal jurisdiction only when proper service has been made under the statute. ${ }^{68}$ Thus, any discussion of personal jurisdiction should take into account the available methods for serving process on the defendant.

Procedures for service of process. The service of process provisions applicable to foreign states and their instrumentalities are set out in the

1605-1607, requires some connection between the lawsuit and the United States . . . . These immunity provisions, therefore, prescribe the necessary contacts which must exist before our courts can exercise personal jurisdiction."); see also 1976 Hearings, supra note 30 , at 31 (statement of Bruno Ristau).

65. See Texas Trading \& Milling Corp. v. Federal Republic of Nigeria, 647 F.2d 300 (2d Cir. 1981); Thomas P. Gonzales Corp. v. Consejo Nacional de Produccion de Costa Rica, 614 F.2d 1247 (9th Cir. 1980); Chicago Bridge \& Iron Co. v. Islamic Republic of Iran, 506 F. Supp. 981 (N.D. Ill. 1980); Verlinden B.V. v. Central Bank of Nigeria, 488 F. Supp. 1284 (S.D.N.Y. 1980), affd on other grounds, 647 F.2d 320 (2d Cir. 1981); Waukesha Engine Div., Dresser Americas, Inc. v. Banco Nacional de Fomento Cooperativo, 485 F. Supp. 490 (E.D. Wis. 1980); Harris v. VAO Intourist, Moscow, 481 F. Supp. 1056 (E.D.N.Y. 1979); East Europe Domestic Int'l Sales Corp. v. Terra, 467 F. Supp. 383 (S.D.N.Y.), affd mem., 610 F.2d 806 (2d Cir. 1979); Upton v. Empire of Iran, 459 F. Supp. 264 (D.D.C. 1978), affd mem. , 607 F.2d 494 (D.C. Cir. 1979); Carey v. National Oil Corp., 453 F. Supp. 1097 (S.D.N.Y. 1978), affd per curiam, 592 F.2d 673 (2d Cir. 1979); National Am. Corp. v. Federal Republic of Nigeria, 448 F. Supp. 622 (S.D.N.Y. 1978), affd, 597 F.2d 314 (2d Cir. 1979); see also Carl, Suing Foreign Govemments in American Courts: The Uniled Stales Foreign Sovereign Immunilies Act in Practice, 33 Sw. L.J. 1009 (1979).

66. 326 U.S. 310 (1945).

67. Id. at 316. Several subsequent Supreme Court decisions have interpreted and expanded upon the International Shoe standard. See Hanson v. Denckla, 357 U.S. 235 (1958); Shaffer v. Heitner, 433 U.S. 186 (1977); Kulko v. Superior Court, 436 U.S. 84 (1978); WorldWide Volkswagen Corp. v. Woodson, 444 U.S. 286 (1980); Rush v. Savchuk, 444 U.S. 320 (1980).

68. See 28 U.S.C. § 1330(b) (1976). 
Act and fill a previous vacuum in the law. ${ }^{69}$ The service provisions are divided into two parts, one for service on foreign states themselves, the other for service on the agencies or instrumentalities of foreign states. All provisions are designed to result in the most effective notice possible, given the peculiar problems of dealing with defendants from different cultures who may or may not be fluent in English. If service is not accomplished as provided under the statute, then personal jurisdiction is lacking and the suit must be dismissed. ${ }^{70}$

The statute sets out a hierarchy of four methods of service on foreign state defendants. The favored method is to comply with any special arrangements for service that exist between the plaintiff and the foreign state. ${ }^{71}$ This provision should encourage parties contracting with foreign states to agree on service procedures in order to avoid later problems. ${ }^{72}$ Absent such an agreement, the plaintiff should serve the summons and complaint in accordance with any international convention on the service of judicial documents to which both the United States and the defendant state are signatories. $^{73}$ If no convention applies, the plaintiff may have the clerk of the court mail a copy of the summons and complaint and a notice of the suit, in English and translated into the official language of the foreign state, to the head of the ministry of foreign affairs of the de-

69. Id. $\S 1608$. Prior to 1976 , there was no specific authorization in the Federal Rules of Civil Procedure or in state statutes for service on foreign governments. See Miller, Service of . Process on Stale, Local and Foreign Governments Under Rule 4, Federal Rules of Civil Procedure-Some Unfinished Business for the Rulemakers, 46 F.R.D. 101, 121-39 (1969) (discussion of service practices prior to the Act). Courts strained to apply existing service provisions to foreign government defendants, and some courts ruled that they could develop ad hoc procedures to fill the void as long as due process concerns were met. Because of the absence of any clearly applicable service provisions, actions commonly were begun by the attachment of the foreign state's property. See, e.g., Victory Transport, Inc. v. Comisaria General de Abastecimientos y Transportes, 336 F.2d 354, 363 (2d Cir. 1964), cert. denied, 381 U.S. 934 (1965); National Am. Corp. v. Federal Republic of Nigeria, 448 F. Supp. 622, 633 (S.D.N.Y. 1978), affd, 597 F.2d 314 (2d Cir. 1979); Note, Sovereign Immunity-Limils of Judicial Control, 18 HARV. INT'L L.J. 429, 443 (1977).

70. See, e.g. , 40 D 6262 Realty Corp. v. United Arab Emirates Gov't, 447 F. Supp. 710 (S.D.N.Y. 1978); Gray v. Permanent Mission of People's Republic of Congo, 443 F. Supp. 816 (S.D.N.Y.), affd mem., 580 F.2d 1044 (2d Cir. 1978).

71. 28 U.S.C. $§ 1608(a)(1)$ (1976).

72. See HOUSE REPORT, supra note 18, at 24, reprinted in [1976] 5 U.S. CODE CONG. \& AD. NEws $6604,6623$.

73. 28 U.S.C. $§ 1608(a)(2)$ (1976). The only service convention to which the United States presently is a party is the Hague Convention on Service Abroad of Judicial and Extrajudicial Documents, done Nov. 15, 1965, 20 U.S.T. 361, T.I.A.S. No. 6638. This method of service is available only in actions against other signatory states. For a current listing of adhering nations, see the latest edition of the annual Department of State publication Treaties in Force, or the annotations to FED. R. Crv. P. 4 in 28 U.S.C.A. (West 1960 \& Supp. 1981). 
fendant foreign state. A signed receipt for this mailing must be procured from the defendant. ${ }^{74}$ Only if the plaintiff cannot accomplish the mail service just described within thirty days may diplomatic means be used. ${ }^{75}$ This last method requires the clerk to send all the aforementioned documents and translations to the office of the Secretary of State to be transmitted through diplomatic channels. ${ }^{76}$

The statutory provisions governing service on agencies or instrumentalities of foreign states reveal a similar hierarchical approach, favoring service in accordance with special arrangements or applicable international conventions. ${ }^{77}$ However, depending on the character of the defendant instrumentality, additional service methods are permissible. Treating the foreign instrumentalities like private corporations, the plaintiff may serve process on any officer, managing or general agent, or agent authorized to receive process in the United States. ${ }^{78}$ As a last resort, service of the summons and complaint, accompanied by appropriate translations, may be made in accordance with procedures designated by an authority of the foreign state in response to a letter rogatory, by mail to the instrumentality with a signed receipt required, or as directed by the court as long as the method is consistent with the law of the place where service is made. ${ }^{79}$ Thus, although the methods provided are in some ways less rigid than those governing suits against foreign states, the emphasis on assuring notice by adequate service also characterizes these procedures. ${ }^{80}$

The fact that few problems have arisen to date in the application

74. See 28 U.S.C. $§ 1608(a)(3)$ (1976).

75. See 28 U.S.C. $\$ 1608$ (a)(4) (1976); HOUSE REPORT, supra note 18 , at 24 , reprinled in [1976] 5 U.S. CODE CONG. \& AD. NEWS 6604, 6623.

76. Congress took great care in framing these provisions to assure actual notice to the foreign state. If the plaintiff uses mailed notice or diplomatic channels, the statute mandates that the plaintiff transmit a "notice of suit" in addition to the translations of the summons and complaint. 28 U.S.C. $\S \S 1608$ (a)(3)-(4) (1976). The contents of the notice are prescribed by regulations promulgated by the Secretary of State. 22 C.F.R. $\$ \S 93.1-.2$ (1980). Those require the plaintiff to describe the action and relief requested and to explain in "simplified language" the obligation to answer or to suffer a default. The notice also must include a copy of the Act.

77. 28 U.S.C. $\S 1608(b)(1)-(2)(1976)$.

78. Id. $\S 1608(\mathrm{~b})(2)$. This list of persons authorized to receive process for the instrumentality of a foreign state is nearly identical to the list of persons authorized to receive federal process on behalf of corporate defendants. See FED. R. Crv. P. 4(d)(3).

79. 28 U.S.C. $\$ 1608(\mathrm{~b})(3)$ (1976). This provision essentially incorporates the methods for service in a foreign country that already are part of the federal rules. See FED. R. CIV. P. 4(i).

80. One difference of particular note is that a plaintiff serving an agency or instrumentality need not include with the summons and complaint and translations any notice of suit. 
of these requirements attests to their value. Still, interpretative difficulties may arise. For example, plaintiffs must be able to determine whether the defendants they are suing are "foreign states" or "instrumentalities" in order to decide which method of process to use. ${ }^{81}$ If the defendant is an instrumentality, plaintiffs then must determine who qualifies as the agent for service purposes. ${ }^{82}$ Further, if the court must design special service procedures for a given action against a foreign state agency or instrumentality, it must undertake the task of determining foreign law because of the need to make certain that the method chosen comports with the law of the country where service is made. ${ }^{83}$ But these problems seem relatively minor, and further experience under the Act should resolve most ambiguities. ${ }^{84}$

Exclusivity of section 1608 service of process. It is not clear from the text of the Act whether a court can authorize service of process by means other than those listed in the Act unless it finds that the statutory methods are unworkable. For example, if a suit is filed in state court, can the plaintiff use applicable state service procedures rather than federal law? ${ }^{85}$

The legislative history of the Act and the policies underlying it compel the conclusion that its service procedures are meant to be exclusive. ${ }^{86}$ Because Congress was concerned with establishing methods of service that would be effective in notifying the defendant state, the Act requires plaintiffs to use the means most likely to provide adequate notice before turning to less secure methods. To allow a

See note 76 supra. The legislative history contains no explanation for the elimination of the notice of suit requirement in actions against foreign instrumentalities.

81. See, e.g., Gray v. Permanent Mission of People's Republic of Congo, 443 F. Supp. 816, 820 (S.D.N.Y.), affd mem., 580 F.2d 1044 (2d Cir. 1978).

82. See id. at 820 n.4. Since the persons designated in the statute are the same as those in FED. R. Civ. P. 4(d)(3), some guidance on this question can be found in authorities interpreting the federal rule. See generally 4 C. WRIGHT \& A. MILLER, supra note 14, §§ 1100-1104.

83. In New England Merchants Nat'l Bank v. Iran Power Generation \& Transmission Co., 495 F. Supp. 73, 78-79 (S.D.N.Y. 1980), the court found that it was not possible to obtain a definitive statement regarding Iranian law governing permissible service methods and thus ruled that the method used did not need to be identical to the law of the foreign state, so long as it was not prohibited under that law.

84. A court may refer to cases interpreting and applying FED. R. CIV. P. 4(i) for guidance in applying the procedures set out in 28 U.S.C. $\$ 1608(b)(3)$ (1976). See 4 C. WRIGHT \& A. MiLler, supra note $14, \S \S 1133-1136$.

85. As a practical matter, the potential for applying alternative service procedures should occur only when suit is filed in state court since the Act provides the exclusive means of service of process in the federal courts. See text accompanying note 86 infra.

86. See HOUSE REPORT, supra note 18, at 23-24, reprinted in [1976] 5 U.S. CODE CONG. \& AD. NEws 6604, 6622-23. 
plaintiff to circumvent this entire scheme merely by filing suit in a state court and invoking its procedures appears to be inconsistent with the Act's goal of promoting the uniform treatment of actions against foreign sovereigns. The conclusion that federal law governs may require the states to follow procedures uncommon to their judicial systems and may, in some sense, represent a serious burden on the state courts. Nonetheless, this result is justified by the federal government's need to control relations with foreign governments.

Although the exclusivity of the service provisions in the Act seems necessary in the face of competing state procedures, courts may have the power to create an ad hoc approach to service when the statutory requirements cannot be satisfied in actions against foreign states. In suits against foreign agencies or instrumentalities, the Act authorizes the court to create a service procedure when other methods are unavailable. ${ }^{87}$ The absence of a catch-all provision in the section dealing with foreign states may suggest that Congress did not want to confer that authority on the courts. But is is more likely that the omission was a drafting oversight occurring because Congress never considered that a situation would arise in which service could not be made through diplomatic channels. This country's difficulties with Iran since 1979 have resulted in just such a situation.

In New England Merchants National Bank v. Iran Power Generation $\mathcal{E}^{\circ}$ Transmission Co. ${ }^{88}$ the plaintiffs sued in the federal district court for wrongs arising from Iran's policy of nationalization and its repudiations of executory contracts. Attempts to serve process on Iran under the Act were futile. The court refused to adopt the defendant's theory that congressional silence constituted a total prohibition of alternative means for service of process. ${ }^{89}$ Instead, it held that Rule 4(i), ${ }^{90}$ which provides procedures for service in a foreign country, may supplement the statutory methods and that the Rule authorizes the federal courts to fashion an appropriate procedure. ${ }^{91}$ The court ordered service by Telex in Farsi and English to the defendants stating the text of the summons, the notice of suit, and notice that the pleadings were being mailed under separate cover. Further, the court ordered the pleadings to be served on all counsel who had filed a notice of appearance on behalf of any of the defendants. ${ }^{92}$ While the ad hoc

87. 28 U.S.C. § 1608(b)(3)(C) (1976).

88. 495 F. Supp. 73 (S.D.N.Y. 1980).

89. Id. at 79 .

90. FED. R. Giv. P, 4(i).

91. 495 F. Supp. at 80 n.2.

92. Id. at 81 . 
power used by the court in New England Merchants should be limited to those extraordinary situations in which none of the statutory procedures work, the authority of the court to act in those situations seems justified. The only concern must be to devise the method most likely actually to notify the defendant state. ${ }^{93}$

\section{Satisfying the International Shoe standard. ${ }^{94}$}

Personal jurisdiction and immunity. Many of the cases arising under the Act reveal a marked confusion in their application of the minimum contacts doctrine. This confusion results from the Act's blend of procedural and substantive criteria into a single, unified standard and from the failure of the courts to understand how to apply traditional jurisdiction doctrines within this unique framework. ${ }^{95}$

Personal jurisdiction requires sufficient contacts of the defendant with the forum to assure fairness to a nonresident defending away from home. The substantive law of sovereign immunity involves considerations of whether a state has acted outside its official capacity so that it is possible to provide a remedy for an injured plaintiff without abandoning the general respect given to foreign governments.

A decision that sovereign immunity should not be upheld does

93. Only one method that would seem likely to be effective is expressly precluded in the legislative history of the Act: Service may not be accomplished by mailing process to the state's embassy. Congress wanted to preclude service on an embassy by mail in order to avoid problems that might arise concerning possible violations of the Vienna Convention on Diplomatic Relations, opened for signature Apr. 18, 1961, 23 U.S.T. 3227, T.I.A.S. No. 7502 . See HOUSE REPORT, supra note 18, at 26, reprinted in [1976] 5 U.S. CODE CONG. \& AD. NEwS 6604,6625 .

94. One must be aware when discussing the International Shoe standard that the Supreme Court case names are slightly misleading. The Act deals with matters truly international and world-wide in scope. Intermational Shoe was not international at all-the defendant was a Missouri corporation; World-Wide Volkswagen involved an American subsidiary of a foreign concern doing business in New York. The exclusive subject of Supreme Court adjudication in this area has been making geographic allocation within the United States itself, not determining the reach of American process, state or federal, beyond the national boundaries. It is this latter question which now occupies us. The problems probably are similar-due process concerns apply to all parties in American courts-but we should be conscious that they are not identical.

95. See, e.g., Chicago Bridge \& Iron Co. v. Islamic Republic of Iran, 506 F. Supp. 981, 982 n.2 (N.D. Ill. 1980) (personal jurisdiction raised sua sponte since related to immunity, which is tied to subject matter jurisdiction, which is never waived); see also notes 14-15 supra. Unfortunately, the American Law Institute has not taken the opportunity in its revision of the Restatement of Foreign Relations Law of the United States to clarify these jurisdiction issues, but has accepted the statute's blended immunity-jurisdiction approach uncritically. See RESTATEMENT of Foreign RELATIONS LAW OF THE UNited States (Revised) $\$ 453$, comment c, at 184 (Tent. Draft No. 2, 1981). 
not mean, therefore, that the tribunal in which suit is filed is a fair one in due process terms. In contrast, the defendant state may have such extensive contacts with the United States that the minimum contacts standard clearly would support the assertion of personal jurisdiction, but the activity on which the suit is filed may not be sufficiently commercial to fall within an exception to immunity. Despite these underlying differences, several courts have assumed that the immunity sections serve essentially as the long-arm provisions of the Act and that it is those sections that must be construed in light of International Shoe. ${ }^{96}$ Other courts have gone further and have attempted to construe those immunity provisions not only in light of minimum contacts, but also in keeping with the interpretation of similar language in their own jurisdictions' long-arm statutes. ${ }^{97}$

The decision as to what law and policies should be consulted when deciding to assert jurisdiction against a foreign sovereign is critical. As the legislative history makes clear, the Act should promote a uniform body of law so that foreign state defendants, as well as private plaintiffs, can predict their exposure to suit and act accordingly. ${ }^{98}$ Yet, construction of the statute to date is far from uniform. Further, it is not clear that the Act, as applied, adequately advances the goals underlying the restrictive immunity approach. ${ }^{99}$

Keeping separate the jurisdiction and immunity questions, at least for purposes of analysis, allows a coherent approach to each is-

96. See Ohntrup v. Firearms Center, Inc., 516 F. Supp. 1281, 1286-87 (E.D. Pa. 1981); Verlinden B.V. v. Central Bank of Nigeria, 488 F. Supp. 1284, 1293 (S.D.N.Y. 1980), affd on other grounds, 647 F.2d 320 (2d Cir. 1981); Carey v. National Oil Corp., 453 F. Supp. 1097, 1101 (S.D.N.Y. 1978), affd per curiam, 592 F.2d 673 (2d Cir. 1979).

97. See Thomas P. Gonzalez Corp. v. Consejo Nacional de Produccion de Costa Rica, 614 F.2d 1247 (9th Cir. 1980); Waukesha Engine Div., Dresser Americas, Inc. v. Banco Nacional de Fomento Cooperativo, 485 F. Supp. 490 (E.D. Wis. 1980); East Europe Domestic Int'l Sales Corp. v. Terra, 467 F. Supp. 383 (S.D.N.Y. 1979) (referring to the District of Columbia long-arm statute), aff'd mem., 610 F.2d 806 (2d Cir. 1979); Upton v. Empire of Iran, 459 F. Supp. 264 (D.D.C. 1978), affd mem., 607 F.2d 494 (D.C. Cir. 1979).

98. See HOUSE REPORT, supra note 18, at 12-13, reprinted in [1976] 5 U.S. CODE CONG. \& AD. NEws 6604,6611 . The United States then could avoid disputes with foreign nations caused by disparate treatment of foreign nations in the courts.

99. Judge Weinstein explained, "The insuperable problem faced by the plaintiff arises because of the Immunities Act's policy and its conflation of the doctrines of subject matter jurisdiction, in personam jurisdiction and sovereign immunity. Despite the rule that "[s]overeign immunity is a derogation from the normal exercise of jurisdiction by the courts and should be accorded only in clear cases,' . . . Congress has given the courts little room to maneuver in a case such as the one now before us." Harris v. VAO Intourist, Moscow, 481 F. Supp. 1056, 1065 (E.D.N.Y. 1979) (citation omitted). 
sue. ${ }^{100}$ Moreover, increased clarity of analysis and uniformity in decision would result if the courts would interpret the statutory provisions in light of the policies underlying the doctrine of sovereign immunity-especially the function of immunity in preventing foreign policy disputes. This means that only federal law should govern such questions; judicial interpretations of state long-arm statutes are irrelevant to deciding claims of immunity. Once the court decides that the foreign state is not immune, it must consider-as it does for every defendant-whether asserting jurisdiction would violate notions of minimum contacts and fair play. Here, too, a federal standard would control.

Separating immunity and personal jurisdiction concerns will not always dictate different results in deciding whether personal jurisdiction is proper. Indeed, none of the above discussion should be read to indicate that the courts have been improperly denying or asserting jurisdiction. ${ }^{101}$ The point is that predictability and uniformity will be vastly enhanced if the personal jurisdiction and immunity questions are separated and each is viewed from the proper perspective. In each case it will be necessary to apply the statutory criteria for the exceptions to immunity, and then to consider due process questions.

Applying International Shoe. A brief look at the minimum contacts test as applied to some of the cases that have arisen should illustrate the way a proper personal jurisdiction analysis would proceed. The International Shoe standard requires a nonresident defendant to have had sufficient contacts with the forum so that the assertion of jurisdiction "does not offend 'traditional notions of fair play and substantial justice." "102 The Supreme Court in World-Wide Volkswagen explained that the minimum contacts portion of that test may be satisfied only if the defendant's contact with the forum was such that

100. See, e.g., Texas Trading \& Milling Corp. v. Federal Republic of Nigeria, 647 F.2d 300, 308 (2d Cir. 1981).

101. In many instances the statutory exceptions to immunity authorize a much narrower assertion of jurisdiction than would the more vague "fair play" criteria of International Shoe. See Chicago Bridge \& Iron Co. v. Islamic Republic of Iran, 506 F. Supp. 981, 988 (N.D. Ill. 1980) ("However, the . . . Act's bases of jurisdiction are 'less comprehensive than those found in the usual jurisdictional statutes of the states and the District of Columbia.' ") (citation omitted); notes 107, 113 infra and accompanying texts; see also Verlinden B.V. v. Central Bank of Nigeria, 488 F. Supp. 1284, 1295 (S.D.N.Y. 1980), affd on other grounds, 647 F.2d 320 (2d Cir. 1981).

102. International Shoe Co. v. Washington, 326 U.S. 310, 316 (1945) (quoting Milliken v. Meyer, 311 U.S. 457, 463 (1940)). 
the defendant reasonably could anticipate defending there. ${ }^{103}$ In suits against foreign governments, the relevant contacts are those with the United States, not just those with the forum state. ${ }^{104}$ Thus, a minimum contacts analysis typically would require some activity by which the foreign state has purposefully availed itself of the privileges and benefits of the laws of the United States. ${ }^{105}$ Fairness concerns then require the court to balance numerous factors: the burden on the defendant if jurisdiction is taken, the forum's interest in adjudicating the controversy, the plaintiff's interest in suing in the forum, the availability of an alternate forum, whether judicial efficiency or economy will result if jurisdiction is upheld, and whether any substantive policies will be fostered either by taking or by declining jurisdiction. ${ }^{106}$

One common situation for a lawsuit occurs when an American supplier contracts to sell its product to a foreign government or one of its agencies, and the buyer subsequently repudiates the contract or fails to perform its obligations. Assuming that the defendant cannot claim sovereign immunity because of the commercial nature of its activities, ${ }^{107}$ the issue is whether its contacts with the United States were sufficient to meet the due process standard. To answer this

103. 444 U.S. at 297.

104. See Texas Trading \& Milling Corp. v. Federal Republic of Nigeria, 647 F.2d 300, 314 (2d Cir. 1981). In conventional private party litigation involving foreign defendants, one must ask not only whether the defendant may be sued in the United States, but where therein. In federal courts, FED. R. CIV. P. 4 serves as a geographic allocator by prescribing where and how process may be delivered. In state courts, statutes or rules customarily control. Thus, if a foreign ship threads the St. Lawrence Seaway to Duluth, Minnesota, and some activity there results in a claim of liability, courts in Minnesota might exercise personal jurisdiction over the ship's owners because of the ship's connection with the forum, and process might be served either inside or outside the state of Minnesota under either the Minnesota long-arm statute or under the method provided in Rule 4.

That the defendant owner is a sovereign state changes that result as to the form and mechanics of service because of the Act's express provisions regulating notification of suit. See 28 U.S.C. $\S 1608$ (1976). But the Act is silent on whether the Minnesota courts, state or federal, are the only permissible forums in the United States that can entertain the suit, though the logical deduction is that all courts within the United States, rather than those of any geographic locale, have jurisdiction to proceed. Considerations of the appropriate forum, or the most convenient one, ought to be addressed on motions to transfer on those grounds, rather than dismissing a suit in the District of Columbia or New York for lack of personal jurisdiction-a course that might occur if the ship's owner were private rather than a government. See text accompanying notes 127-42 infra.

105. This notion first appeared in Hanson v. Denckla, 357 U.S. 235, 253 (1958).

106. World-Wide Volkswagen Corp. v. Woodson, 444 U.S. 286, 292 (1980).

107. 28 U.S.C. $\$ 1605$ (a)(2) (1976). For an exploration of the extent of this exception to sovereign immunity, see Kahale \& Vega, supra note 2, at 236-44; Von Mehren, supra note 3, at 48-54; Note, Long-Am Jurisdiction Under the Foreign Sovereign Immunilies Act, 74 AM. J. INT'L L. $640,640-49$ (1980); Note, supra note 3 , at 550-52. 
question, the courts may consider who solicited the contract, where it was entered into, and whether the defendant conducts any additional commercial activity in the United States. ${ }^{108}$ Jurisdiction probably will not be upheld if the court finds that the contract on which the suit is based is the only one which the foreign sovereign has in the United States and that the American plaintiff solicited that agreement. Minimum contacts are not established even if the plaintiff is obliged to perform its obligations under the contract within United States borders; the unilateral acts of the plaintiff do not show that the defendant purposefully availed itself of the privileges and benefits of United States law. ${ }^{109}$

To finish its minimum contacts analysis, the court also must consider the fairness of taking jurisdiction. ${ }^{110}$ Notably, in any action involving a foreign state defendant, it is likely that fairness concerns will tip in favor of upholding jurisdiction. ${ }^{111}$ There will be an enormous interest in providing a United States forum for the settling of the dispute when the plaintiff is an American citizen, ${ }^{112}$ since foreign tribunals may not offer the plaintiff the same protection as a United States court. In addition, the Act represents a substantive decision by Congress concerning how to treat foreign governments in terms of their immunity from liability. The assertion of jurisdiction in an action properly brought under that statute, then, will further the policy of the legislature to allow only restrictive immunity to be invoked. Thus, as a practical matter, in most instances the major hurdle in asserting personal jurisdiction will not be fairness, but the other crite-

108. For decisions finding sufficient contacts in contract cases, see, e.g., Gemini Shipping, Inc. v. Foreign Trade Org. for Chems. \& Foodstuff, 647 F.2d 317 (2d Cir. 1981); Texas Trading \& Milling Corp. v. Federal Republic of Nigeria, 647 F.2d 300 (2d Cir. 1981).

109. See, e.g., Thomas P. Gonzalez Corp. v. Consejo Nacional de Produccion de Costa Rica, 614 F.2d 1247 (9th Cir. 1980) (no minimum contacts when defendants never were present or engaged in business in the state); Waukesha Engine Div., Dresser Americas, Inc. v. Banco Nacional de Fomento Cooperativo, 485 F. Supp. 490 (E.D. Wis. 1980) (that products were made in the United States and defendant had once visited this country were not enough for minimum contacts); $f$. Carey v. National Oil Corp., 453 F. Supp. 1097, 1101 (S.D.N.Y. 1978), affd per curiam, 592 F.2d 673 (2d Cir. 1979) (no minimum contacts when foreign state supplier avoided reach of United States law by selling only to Bahamian subsidiary of American buyer).

110. In the breach of contract actions cited in note 109 supra, in which personal jurisdiction was in issue, the courts declined jurisdiction on the ground that there were insufficient minimum contacts and thus they did not go on to analyze the fairness portion of the standard.

111. See, e.g., Texas Trading \& Milling Corp. v. Federal Republic of Nigeria, 647 F.2d 300, 315 (2d Cir. 1981).

112. When the plaintiff is not an American citizen, the court may, of course, dismiss on forum non conveniens grounds. See text accompanying notes 127-42 infra. 
ria for determining whether sufficient minimum contacts can be found.

Let us consider a case in which the foreign state, acting through an agency or instrumentality, commits a tort within the United States resulting in injury or death. ${ }^{113}$ Traditional minimum contacts analysis makes it clear that jurisdiction would be proper in this situation. The defendant by acting within the United States had reason to foresee being sued there, at least with reference to those activities. The suitability of jurisdiction is more difficult when the tort occurs outside the United States, though the effects of the tort are felt within the United States. ${ }^{114}$ In this situation, the court must inquire whether the defendant carries on other activity within the United States by which it can be said to have purposefully entered into commerce here, as well as whether the tort, though not occurring within the United States, arose in connection with its purposeful activity here. In any case, the greater the connection with the United States, the greater the possibility that foreseeability of suit will be found and the minimum contacts standard met. ${ }^{115}$

\section{Prejudgment attachment.}

In a marked departure from the practice prior to $1976,{ }^{116}$ the Act

113. Foreign sovereigns cannot assert immunity when the state commits a tort within the United States resulting in personal injury, death, or property damage. See 28 U.S.C. $\S 1605(\mathrm{a})(5)$ (1976). Certain torts carry immunity, however. Id. $\S 1605(\mathrm{a})(5)(\mathrm{A})-(\mathrm{B})$. For a fuller discussion of this exception to immunity, see Carl, supra note 65, at 1018-19.

114. See, e.g., Ohntrup v. Firearms Center, Inc., 516 F. Supp. 1281 (E.D. Pa. 1981); In re Rio Grande Transport, Inc., 516 F. Supp. 1155 (S.D.N.Y. 1981); Harris v. VAO Intourist, Moscow, 481 F. Supp. 1056 (E.D.N.Y. 1979); East Europe Domestic Int'l Sales Corp. v. Terra, 467 F. Supp. 383 (S.D.N.Y.), affd mem., 610 F.2d 806 (2d Cir. 1979); Upton v. Empire of Iran, 459 F. Supp. 264 (D.D.C. 1978), affd mem., 607 F.2d 494 (D.C. Cir. 1979).

115. Although the Intemational Shoe standard may be satisfied so that the exercise of personal jurisdiction would be constitutional, sovereign immunity may preclude some of these actions. Absent a waiver, the only exception to immunity that might pertain to torts outside the United States occurs when the court finds that the action was based on "a commercial activity carried on in the United States" or an act outside the United States that was connected with commercial activities of the foreign state and that caused a direct effect in the United States. 28 U.S.C. $§ 1605$ (a)(2) (1976); see, e.g., Ohntrup v. Firearms Center, Inc., 516 F. Supp. 1281 (E.D. Pa. 1981); Harris v. VAO Intourist, Moscow, 481 F. Supp. 1056, 1061 (E.D.N.Y. 1979). The "direct effect" standard does not seem to be satisfied by the mere fact that the injured person is an American citizen. See, e.g., id. at 1065; Upton v. Empire of Iran, 459 F. Supp. 264 (D.D.C.), affd mem., 607 F.2d 494 (D.C. Cir. 1979); Note, supra note 107, at 646-47.

116. Prior to 1976, courts had ruled that property owned by foreign sovereigns could be attached for purposes of asserting jurisdiction over the sovereign, but property owned by foreign governments was totally immune from execution. See Miller, supra note 69, at 126-27; see also Dexter \& Carpenter, Inc. v. Kunglig Jarnvagsstyrelsen, 43 F.2d 705, 708 (2d Cir. 
limits plaintiffs to actions in which they can obtain in personam jurisdiction over the foreign sovereign. ${ }^{117}$ The prejudgment seizure of property for purposes of obtaining quasi in rem or in rem jurisdiction over the defendant is unavailable. ${ }^{118}$ There are three rationales for eliminating quasi in rem and in rem jurisdiction. First, it is no longer necessary to allow additional types of personal jurisdiction, since the Act greatly expands the plaintiff's ability to obtain in personam jurisdiction over foreign sovereigns and provides a means of executing judgments against them. ${ }^{19}$ Second, prejudgment attachments have in the past caused considerable friction with foreign governments, so it may be best to eliminate them except when the sovereign explicitly consents. ${ }^{120}$ Third, prejudgment attachments sometimes have involved United States courts in litigation with foreign sovereigns concerning activities that had few contacts with this country beyond the

1930) (government immunity to counterclaim waived by original suit); Weilamann v. Chase Manhattan Bank, 21 Misc. 2d 1086, 1088, 192 N.Y.S.2d 469, 472 (Sup. Ct. 1959). The rationale for granting immunity from execution was, first, that the property of most territorial sovereigns was exempt from execution under local law and thus that foreign sovereigns should not be less favored; and, second, to deny immunity might threaten peaceful international relations. See Setser, The Immunities of the State and Government Activities, 24 LAW \& CONTEMP. PrOBS. 291, 308 (1959). The result of this practice was that the prevailing litigant often obtained a legally valid but wholly unenforceable judgment. The Act departs from this rule by making the standards for granting immunity from execution conform more closely to those governing jurisdictional immunity. See 28 U.S.C. $\$ \S 1610(a)-(b), 1611$ (1976). This change was supported, in part, on the ground that there is a definite trend in international law toward limiting execution immunity. See HOUSE REPORT, supra note 18, at 27, reprinted in [1976] 5 U.S. CODE CONG. \& AD. News 6604, 6626.

117. The Act authorizes subject matter jurisdiction only "as to any claim for relief in personam." 28 U.S.C. \$1330(a) (1976). Further, at least one court has ruled that the Act's prohibition of prejudgment attachment solely for jurisdictional purposes is so important that quasi in rem jurisdiction is impermissible, see Geveke \& Co. Int'l v. Kompania di Awa i Elektrisidat di Korsou N.V., 482 F. Supp. 660, 663-64 (S.D.N.Y. 1979), even if subject matter jurisdiction may be established outside of $\$ 1330(a)$.

118. The Act allows prejudgment attachment of property owned by a foreign state only when the state explicitly has waived its immunity from attachment and when the purpose of the attachment is to secure the satisfaction of any judgment that ultimately may be entered. 28 U.S.C. $\$ 1610$ (d) (1976). Even this exception is limited by the need to show an explicit, not implicit, waiver. See, e.g., E-Systems, Inc. v. Islamic Republic of Iran, 491 F. Supp. 1294, 1300 (N.D. Tex. 1980); Reading \& Bates Corp. v. National Iranian Oil Co., 478 F. Supp. 724, 728 (S.D.N.Y. 1979).

119. See text accompanying notes 68-84 supra.

120. See HOUSE REPORT, supra note 18, at 26-27, reprinted in [1976] 5 U.S. CODE CONG. \& AD. NEws 6604, 6625-26. Although the loss of the power to obtain a prejudgment attachment, particularly in admiralty cases, might have produced great controversy, no serious objections to that portion of the Act were raised; indeed, the position taken in the statute was viewed as a reasonable compromise. See Note, supra note 3 , at 556, 559-65. 


\section{defendant's limited property interests. ${ }^{121}$}

The elimination of in rem and quasi in rem jurisdiction presents a particularly stark change in admiralty law, where suit traditionally has been filed by arresting a vessel in port, thereby asserting in rem jurisdiction. ${ }^{122}$ In order to discourage the admiralty bar from continuing to use this method of prejudgment seizure, ${ }^{123}$ Congress provided that if the plaintiff improperly arrests a vessel for purposes of filing suit and is not able to show that at the time he was unaware that the vessel was owned by a foreign state rather than a private concern, the required notice of the suit, whether actually received or not, "shall not be deemed to have been delivered, nor may it thereafter be delivered."124

It is important to note that the plaintiff cannot avoid dismissal simply by pleading ignorance of the statutory requirements or the defendant's sovereign capacity. ${ }^{125}$ Thus, the penalty for improperly or even negligently using a prejudgment attachment in admiralty is

121. HOUSE REPORT, supra note 18 , at 26 , reprinled in [1976] 5 U.S. CODE CONG. \& AD. News $6604,6625$.

122. See G. Gilmore \& C. Black, JR., The Law of Admiralty $\S \S 1-12,9-3$ to -4 (2d ed. 1975).

123. The prohibition of prejudgment seizure of vessels of foreign states does not preclude a court from ordering the defendant to post some form of security when it is required to create an equality of security between the parties, rather than to obtain the release of its vessel. See Willamette Transport, Inc. v. Cia. Anonima Venezolana de Navegacion, 491 F. Supp. 442 (E.D. La. 1980).

124. 28 U.S.C. $\$ 1605$ (b)(1) (1976). It is important to consider the potential effect of a dismissal under this section. The Act simply states that the notice shall be treated as though it never was delivered and that it may not be delivered subsequently so as to comply with the statute. Thus, the plaintiff cannot merely file again in admiralty to enforce a maritime lien. However, it is not clear whether the plaintiff is precluded from filing another claim against the same foreign defendant if the other service provisions may be used and if the defendant falls into one of the excepted categories to immunity listed in id. $\S 1605$ (a). This could occur, for example, when the plaintiff in the first action had sought to have both admiralty and nonadmiralty claims decided. The statute and the legislative history are silent on this question. Nonetheless, the strong desire of Congress to avoid the international friction caused by prejudgment seizures seems to argue that the plaintiff would be barred. See Velidor v. L/P/G Benhgazi, 653 F.2d 812 (3d Cir. 1981) (finding extenuating circumstances allowing a later in personam claim, but clearly implying that the suit normally would be barred).

125. In Jet Line Services, Inc. v. M/V Marsa el Hariga, 462 F. Supp. 1165 (D. Md. 1978), the plaintiff brought an in rem action to recover for the cost of cleaning up after a discharge of oil from the defendant's vessel. The president of the plaintiff corporation stated that he had never known of the foreign state's ownership, and that he was not familiar with the Act, and did not have in-house legal counsel. The defendant argued that the ship was flying the Libyan flag and the government of Libya was listed as its owner in Lloyd's Shipping Index. The court dismissed the suit, stating that " $[t] 0$ allow plaintiff to prevail despite its self-proclaimed ignorance of the law would be to encourage a policy of 'attach first, ask later,' and such an attitude would be in flagrant derogation of the policies behind the Immunities Act." Id. at 1176. 
severe. This makes even clearer the determination of Congress that only in personam jurisdiction is available. ${ }^{126}$

\section{Venue and Forum Non Conveniens}

The last question to consider when deciding where to file suit against a foreign sovereign is venue. For actions filed in state court, a plaintiff must consult the relevant state venue provisions. ${ }^{127}$ For suits filed in federal court, the Act provides that venue is proper where the defendant does business or is licensed to do business, ${ }^{128}$ where the vessel or cargo is located in admiralty actions, ${ }^{129}$ or generally, where the property that is the subject of the action is located or where the claim for relief arose. ${ }^{130}$

The Act has some special venue features worth noting. In an action against the instrumentality of a foreign state, a plaintiff can establish venue easily, since the defendant may be located wherever it does business or is licensed to do business. It is more difficult to determine where a foreign state is present outside of its borders, however, so the Act allows for venue in the District of Columbia in actions against foreign states. ${ }^{131}$ This choice recognizes that most foreign governments will have representatives in Washington, making it convenient for them to defend an action there. ${ }^{132}$

Another notable characteristic of the venue provisions is that a plaintiff may file suit in any district where "a substantial part" of the events or omissions underlying the claim for relief occurred, or where

126. One might note that although quasi in rem and in rem jurisdiction are improper in any type of action under the Act, there is no comparable penalty for an improper prejudgment attachment outside the admiralty field. The Act accords admiralty in rem cases special treatment because there was a greater need to provide some enforcement mechanism to force attorneys to abandon the traditional use of in rem jurisdiction in that field. Also, the potential for causing friction with foreign states is enormous in admiralty because attachment ties up the ship, cargo, and crew, and so represents the power to immobilize assets worth millions, irrespective of the amount of the claim involved.

127. Sometimes a search into state law will lead to nothing, because typical state venue statutes provide for suit against a nonresident in any county or district. See F. JAMES \& G. Hazard, Civil Procedure $\S 12.3$ (2d ed. 1977). Foreign states can avoid this result by removal to federal court, but may gain little thereby in terms of geography. Once in federal court, however, a motion to transfer under 28 U.S.C. § 1404(a) (1976) may produce greater benefits.

128. 28 U.S.C. $\S 1391(\mathfrak{f})(3)(1976)$.

129. Id. $\S 1391(\mathrm{f})(2)$.

130. Id. § 1391(f)(1).

131. Id. § 1391(f)(4).

132. See HOUSE REPORT, supra note 18, at 32, reprinted in [1976] 5 U.S. CODE CONG. \& AD. NEWS 6604,6631 . 
the property that is involved is located. ${ }^{133}$ This formulation significantly expands the typical venue designation of "where the claim arose" and recognizes that, as a practical matter, more than one district may be convenient and appropriate for a suit involving complex transactions.

One important unresolved question is whether a court may dismiss on grounds of forum non coriveniens ${ }^{134}$ an action brought by an American plaintiff and in compliance with the venue provisions, if the only alternate forum is in another country. ${ }^{135}$ The answer requires consideration of two issues. First, should the American citizenship of the plaintiff be a compelling or presumptive factor against dismissal? Second, does the governmental character of the defendant suggest that dismissal should be precluded?

Certainly, the citizenship of the plaintiff does not alone justify imposing increased burdens on a defendant trying to establish the inconvenience of the plaintiff's chosen forum. ${ }^{136}$ The courts' discretion to grant forum non conveniens motions already is limited to "exceptional circumstances," 137 and the court must engage in a careful balancing of the interests of the plaintiff, the defendant, and the forum in ruling on any such motion. ${ }^{138}$ But these concerns do not al-

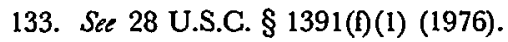

134. Of course, if an action is filed in an improper venue, the defendant state may move to dismiss, or more likely, to transfer the action to a proper district. See 28 U.S.C. \$ 1406 (1976). But the Act does not afford the foreign state any special protection against the ordinary waiver rules. See HOUSE REPORT, supra note 18, at 32, reprinled in [1976] 5 U.S. CODE CONG. \& AD. NEws 6604,6631 . Thus, as is true in actions against defendants other than foreign states, the failure to make a timely objection to venue will act as a waiver of that defense under FED. R. Civ. P. 12(h)(1). See 5 C. Wright \& A. Miller, supra note 14, § 1391.

135. The Supreme Court long has recognized that venue statutes merely establish a presumption of convenience, and if the defendant can show the chosen forum is very inconvenient, the court has discretion to dismiss the action. See Gulf Oil Corp. v. Gilbert, 330 U.S. 501 (1947). A court may invoke this well-established power in suits against foreign sovereigns, as there is nothing in the Act to suggest that Congress meant to eliminate judicial discretion in this area. See Paterson, Zochonis (U.K.) Ltd. v. Compania United Arrow, S.A., 493 F. Supp. 621, 625 n.9 (S.D.N.Y. 1980) (suggesting that forum non conveniens motions may be used in suits under the Act). Indeed, when alien plaintiffs sue foreign states in actions in which the underlying transaction has little connection with the United States, the use of forum non conveniens can eliminate burdensome litigation in which the United States has no interest.

136. See Alcoa S.S. Co. v. M/V Nordic Regent, 453 F. Supp. 10 (S.D.N.Y. 1978), affd, 654 F.2d 147 (2d Cir. 1980) (en banc), cert. denied, 449 U.S. 890 (1980); Note, Forum Non Conveniens and American Plaintiffs in the Federal Courts, 47 U. CHI. L. REv. 373 (1980).

137. Gulf Oil Corp. v. Gilbert, 330 U.S. 501, 504 (1947).

138. That balance may take into account the special burdens on an American plaintiff forced to litigate in a foreign tribunal, including language barriers, distance, and unfamiliarity with the foreign legal system. See Note, supra note 136, at 383. 
ways compel denial of dismissal as, for example, when the plaintiff is an American corporation engaged in a continuous international business and is fully capable of assuming the burdens of litigating in a foreign forum. Thus, though a court may grant forum non conveniens motions less frequently when the only alternate forum is in a foreign country, ${ }^{139}$ it should not reject these motions without undertaking a careful analysis of the facts as they relate to the actual convenience of those involved.

The fact that the defendant is a foreign government raises additional concerns that argue against dismissal. Prior to 1976, because the State Department decided questions of sovereign immunity and because no effective procedures governed suits against foreign governments, an American plaintiff with a claim against a foreign government had no assurance that the suit would be allowed to go forward. ${ }^{140}$ One of the purposes of the Act was to provide American plaintiffs access to their own courts to resolve these disputes. ${ }^{141}$ Given this policy, the presumption favoring a plaintiff's choice of an American tribunal over a foreign one seems even stronger than in other types of actions, especially when there is reason for concern about the fairness or impartiality of litigating against a foreign state in its own tribunals. This does not mean that the court never should grant a forum non conveniens dismissal to a defending state, but it does suggest that the standards for obtaining a dismissal may be more rigidly applied against motions by foreign state defendants, and that dismissal may be very infrequent. ${ }^{142}$

\section{Procedures in Actions Against a Foreign Sovereign}

\section{A. Special Procedures Affecting Foreign State Defendants}

The Act alters only three of the procedural rules normally applicable to civil actions in the federal courts. First, it gives foreign state defendants 60 days to answer after service of process, instead of the usual 20 day period for nongovernment defendants. ${ }^{143}$ Second, it allows judgment by default only if the plaintiff establishes the claim for

139. See, e.g., Aigner v. Bell Helicopters, Inc., 86 F.R.D. 532, 543 (N.D. Ill. 1980).

140. For a discussion of the practices prior to the Act, see note 3 supra.

141. See 1976 Hearings, supra note 30, at 24 (statement of Monroe Leigh).

142. Given that most of the statutory exceptions to immunity require the defendant state to have some connection with the United States, see 28 U.S.C. $\$ \S 1605,1607$ (1976), it is unlikely that any litigation will have so little connection with the United States as to warrant forum non conveniens dismissal.

143. See id. § 1608(d). 
relief "by evidence satisfactory to the court," instead of treating the default as a concession of liability. ${ }^{144}$ Third, the Act appears to prohibit jury trials in suits against foreign sovereigns. ${ }^{145}$ Except for these provisions-each obviously designed to place foreign governments in parity with our own federal government ${ }^{146}$ - the Act allows the same procedural rules to apply as those for ordinary lawsuits. ${ }^{147}$

But applying certain ordinary procedures may raise special problems when foreign state defendants are present. For example, when the foreign state is one of a number of defendants, both the requirements of Rule $13(\mathrm{~g})$ and sovereign immunity limit the ability of co-defendants to file cross-claims against the foreign state. ${ }^{148}$ It also should be necessary to follow the Act's service provisions for cross-claims as well as for original actions, since the policy of assuring notice to foreign states by setting forth detailed and binding service rules requires that they be applied to any claim filed against the foreign state. ${ }^{149}$

Similarly, the operation of discovery against foreign state defendants may cause special problems, particularly if the information or documents that the plaintiff seeks are not present in the United States. ${ }^{150}$ The lessons learned in suits against private defendants when discovery must be carried on in a foreign country should apply here, ${ }^{151}$ though special governmental privileges, such as a privilege to

144. $I d . \S 1608(\mathrm{e})$.

145. See notes 187-201 infra and accompanying text.

146. The United States government has 60 days to answer, see FED. R. Civ. P. 12(a), default judgments against it may be entered only when the plaintiff establishes the claim "by evidence satisfactory to the court," see FED. R. CIV. P. 55(e), and there is no right to a jury trial in actions brought against the United States, see 28 U.S.C. \$ 2402 (1976).

147. The Federal Rules of Civil Procedure will govern actions filed in federal court, while the relevant state procedural rules control actions filed in state court. State courts need not apply the federal rules even though the action involves a foreign state and thus, at least arguably, a strong federal interest. Congress recognized that allowing suits to be filed in the state courts might result in some disparate treatment of foreign state defendants, but rather than providing for uniform procedures to govern all these actions, it made such procedurcs available at the option of the defendant through an unlimited right of removal. See 28 U.S.C. $\S 1441$ (d) (1976).

148. See id. $\S \S 1604-1606$ (sovereign immunity); FED. R. Crv. P. $13(\mathrm{~g})$ (limiting crossclaims to claims against co-parties arising out of the same transaction or occurrence as the original action or any counterclaim therein or relating to property that is the subject matter of the original action).

149. See notes 68-84 supra and accompanying text.

150. See, e.g., Societe Internationale Pour Participations Industrielles et Commerciales v. Rogers, 357 U.S. 197 (1958); see also Note, Foreign Nondisclosure Laws and Domestic Discovery Orders in Antitrust Litigation, 88 YALE L.J. 612 (1979).

151. Discovery in foreign countries frequently depends upon cooperation between the officials of the country whose court is seeking discovery and those of the country where the 
prevent disclosure of state secrets, may preclude discovery of information that could be obtained from a private defendant. ${ }^{152}$

Two issues deserve further consideration: first, the rules that should govern the interjection and proof of sovereign immunity; and second, the possibility of a jury trial in an action against a foreign state. The remainder of this article explores these issues.

\section{B. Raising and Proving Sovereign Immunity}

The procedural treatment of sovereign immunity has been a problem since suits were first brought against governmental entities. The confusion stems from the fact that immunity issues seem to bear on jurisdictional concerns or, at least, are expressed in jurisdictional terms-that is, whether a court has the power to adjudicate matters involving the sovereign. At the same time, sovereign immunity as a concept derives from the need to protect governments from bothersome-if not potentially ruinous-lawsuits, as well as from notions of international comity and respect for the power and dignity of the government. ${ }^{153}$ Thus, immunity is also a defense that may be waived if the sovereign does not desire to invoke that protection.

In American law, the choice whether to treat the sovereign immunity question as a jurisdictional prerequisite or as an affirmative defense is important because it controls the rules prescribing how, when, and by whom the issue can be raised. Courts may answer questions such as who bears the burden of pleading and proving sovereign immunity, or whether failure to raise the issue in a timely fashion waives immunity, or whether a defendant may collaterally attack a judgment on the ground of sovereign immunity, only when they have decided whether immunity is a matter of jurisdiction or is an affirmative defense. Fortunately, the Act provides some guidance in characterizing sovereign immunity, though it is neither completely clear nor comprehensive in addressing this problem.

The Act does not explicitly deal with the pleading and proof of sovereign immunity. Indeed, it seems to contain conflicting signals. On the one hand, the provision authorizing federal court subject matter jurisdiction in actions against foreign sovereigns rests the

discovery is to take place. Parties must consult various specialized rules and procedures regarding such cooperation. See 8 C. WRIGHT \& A. MILLER, supra note 14, $\$ 2083$; Miller, Intemational Cooperation in Litigation Between the United Stales and Switzerland: Unilateral Procedural Accommodation in a Test Tube, 49 MINN. L. REv. 1069 (1965); Smit, International Litigation Under the United States Code, 65 Colum. L. Rev. 1015 (1965).

152. See 8 C. WRIGHT \& A. MILlER, supra note 14, § 2019.

153. See, e.g., National City Bank v. Republic of China, 348 U.S. 356, 362 (1955). 
court's jurisdiction on a finding that the defendant is not entitled to immunity. ${ }^{154}$ This suggests that immunity is jurisdictional and the plaintiff thus would assume the burdens of pleading and proving the jurisdictional prerequisite in keeping with traditional rules. ${ }^{155} \mathrm{On}$ the other hand, the Act sets forth sovereign immunity as a basic principle allowing exceptions only in specified cases. ${ }^{156}$ This reflects the evolution of sovereign immunity as an affirmative defense, a legacy Congress has acknowledged. ${ }^{157}$

In practice, most courts have followed the latter approach and treated immunity as a defense, placing the burden of pleading and proving immunity on the defendant state. ${ }^{158}$ But given the Act's conflicting characterizations of the issue, it is not surprising that no consistent procedure for raising immunity has evolved and that litigants are uncertain about the proper method for introducing a sovereign immunity question. ${ }^{159}$

Similar confusion exists in allocating the burden of proof between the litigants. Insofar as immunity is treated as an affirmative defense, the ultimate burden of proving that any defendant state's activities are immune should rest on that state. However, the legislative history of the Act indicates that Congress envisioned a more complex scheme in which the foreign state merely has the burden to produce prima facie evidence of immunity. According to this scheme, the plaintiff must show that the state's activities fall into one of the statutory exceptions to immunity, and the state retains the

154. 28 U.S.C. § 1330(a) (1976).

155. See C. WRIGHT, supra note $23, \S 69$.

156. See 28 U.S.C. $\S \S 1604-1605$ (1976).

157. According to the House Report,

[s]tating the basic principle in terms of immunity may be of some advantage to foreign states in doubtful cases, but, since sovereign immunity is an affirmative defense which must be specially pleaded, the burden will remain on the foreign state to produce evidence in support of its claim of immunity.

HOUSE REPORT, supra note 18, at 17, reprinted in [1976] 5 U.S. CODE CONG. \& AD. NEws $6604,6616$.

158. See, e.g., Arango v. Guzman Travel Advisors Corp., 621 F.2d 1371, 1378 (5th Gir. 1980); Behring Int'l, Inc. v. Imperial Iranian Air Force, 475 F. Supp. 383, 389 n.16 (D.N.J. 1979).

159. See Sugarman v. Aeromexico, Inc., 626 F.2d 270 (3d Cir. 1980) (motion for summary judgment on immunity grounds); Waukesha Engine Div., Dresser Americas, Inc. v. Banco Nacional de Fomento Cooperativo, 485 F. Supp. 490 (E.D. Wis. 1980) (letters protesting jurisdiction sent to foreign court which had participated in service of process); Perez v. The Bahamas, 482 F. Supp. 1208 (D.D.C. 1980) (motions to dismiss for lack of subject matter and personal jurisdiction on grounds of immunity); Behring Int'l, Inc. v. Imperial Iranian Air Force, 475 F. Supp. 383, 389-90 (D.N.J. 1979) (immunity raised sua sponte). 
ultimate burden of proving immunity. ${ }^{160}$ How these rather artificial shifting burdens will operate is yet to be seen.

The persistent attempts by the courts and the legislature to force sovereign immunity into traditional molds has caused much of the procedural confusion surrounding the issue by obscuring what should be the central inquiry: how to develop procedures for raising and proving immunity that take into account the special concerns surrounding the doctrine. Moreover, applying our familiar approaches automatically to questions of sovereign immunity overlooks that these approaches are not necessarily traditional outside the United States, ${ }^{161}$ and that courts should take care to establish procedures that defendants not familiar with our traditions can understand.

\section{Raising questions of sovereign immunity: who, when, and how.}

This inquiry focuses on three related issues. First, who should bear the burden of interjecting the issue of sovereign immunity into the proceeding? ${ }^{162}$ Second, what timing restrictions should be placed on the right to raise a sovereign immunity question before inactivity will act as a waiver of immunity? Finally, what are the procedures for introducing the immunity issue into the action?

The answer to the first question seems relatively clear. Since the principal purpose of immunity is to protect the interests of the foreign state, the state should bear the burden of asserting the doctrine if it desires that protection. ${ }^{163} \mathrm{~A}$ court is under no obligation to investigate questions of immunity on its own motion and indeed, in fairness to the plaintiff, should not do so. Although these conclusions are incompatible with the characterization of immunity as a jurisdictional requirement, they are nonetheless consistent with the general approach to immunity taken in the Act, which recognizes that states

160. See HOUSE REPORT, supra note 18, at 17, reprinted in [1976] 5 U.S. CODE CONG. \& AD. News $6604,6616$.

161. For example, rigid pleading rules and waiver results are anomalous to lawyers and judges trained in civil law systems. See, e.g., Kaplan, von Mehren \& Schaefer, Phases of German Civil Procedure I, 71 HaRv. L. REv. 1193, 1212-13 (1958).

162. The burden of interjecting a sovereign immunity question into an action should be distinguished from the burden of proving immunity, which may raise other policy considerations. See notes 180-86 infra and accompanying text.

163. The legislative history of the Act suggests this conclusion, although there it is phrased in terms of whether immunity is an affirmative defense that the state must plead. See note 157 supra. Moreover, the notion that a party for whom a special protection is provided in the law has the obligation of invoking that protection or losing it is common throughout American procedure. See, e.g. , F. JAMEs \& G. HAZARD, supra note 127, § 12.22. 
are not absolutely immune from suit. Given that states legitimately can be sued for certain activities, it is appropriate to place on them the burden of asserting that the activity under the court's consideration is in the category remaining immune.

It is more difficult to ascertain the stage of the proceedings at which the defendant foreign state loses the right to claim immunity. Since immunity concerns revolve around issues unrelated to the merits of the dispute and require dismissal when properly invoked, judicial economy and common sense argue that the defendant should raise immunity early in the proceedings. The Act specifically recognizes that a foreign state may waive its immunity "either explicitly or by implication;" 164 moreover, Congress contemplated that an implied waiver would arise from failure to raise immunity in the responsive pleading. ${ }^{165}$ Thus, if a foreign state defendant does not raise the immunity issue at some early stage-for example, before the pleadings are closed-then it may be appropriate for the court to rule that the defendant has by its inactivity impliedly waived its right to claim immunity. ${ }^{166}$

The Act is silent on the question of how to raise immunity. The general approach to the treatment of preliminary issues not involving the merits is to allow, or in some instances to require, that parties raise them in the answer, or in pretrial motions to dismiss or for summary judgment, or by way of special appearances for the purpose of addressing the issue. Because of the central importance of sovereign immunity, the focus should not be on requiring compliance with specified procedural devices for raising the issue, thereby setting traps for litigants unfamiliar with our judicial system. ${ }^{167}$ As long as the court makes an early determination of immunity, judicial economy concerns will be satisfied. ${ }^{168}$ The sole question, therefore, is one of

164. 28 U.S.C. $§ 1605(a)$ (1) (1976) (emphasis added).

165. See HOUSE REPORT, supra note 18 , at 18 , reprinted in [1976] 5 U.S. CODE CONG. \& AD. NEwS 6604, 6617.

166. See In re Rio Grande Transport, Inc., 516 F. Supp. 1155, 1159 (S.D.N.Y. 1981) (filing of conditional counterclaim does not act as implied waiver); Castro v. Saudi Arabia, 510 F. Supp. 309, 311-12 (W.D. Tex. 1980) (failure to answer is not implied waiver).

167. For an example of a straightforward, nontechnical approach to this problem, see European Convention on State Immunity, May 16, 1972, art. 3, Europ. T.S. No. 74 ("1. A Contracting State cannot claim immunity from the jurisdiction of a court of another Contracting State if, before claiming immunity, it takes any step in the proceedings relating to the merits. However, if the State satisfies the court that it could not have acquired knowledge of facts on which a claim to immunity can be based until after it has taken such a step, it can claim immunity based on these facts if it does so at the earliest possible moment.").

168. Thus, it should not matter in a federal court action whether the foreign state introduces immunity by way of a motion to dismiss for lack of jurisdiction, FED. R. Clv. P. 
timeliness. ${ }^{169}$

As a matter of policy, this flexible approach to the procedures for interjecting immunity is not only justified, but compelled. Nonetheless, it does alter some of the familiar rules governing preliminary determinations of other issues. For example, in the federal courts, the application of Rule 12(g) requires the consolidation of all pretrial motions to dismiss. ${ }^{170}$ If this rule were applied, a foreign state might waive sovereign immunity if it previously had raised some other preliminary defense such as insufficient service of process. ${ }^{171}$

Procedures of this type should not apply to sovereign immunity. The imposition of technical restrictions on the ability of a foreign state to claim sovereign immunity could create needless international friction. Foreign government defendants should not lose the right to immunity merely because of an inadvertent misunderstanding of local court practices. That Congress recognized the possibility of an implied waiver merely reflects an understanding that a state may by its action or inaction convey a lack of interest in raising immunity. It does not suggest what procedures should be used in connection with the assertion of the issue.

The final question concerning how to raise sovereign immunity is whether a foreign sovereign may successfully assert immunity as a means of collaterally attacking a judgment. The answer depends, at least in part, on where the collateral attack is made. If the judgment holder seeks to enforce the judgment outside the United States, and especially in the courts of the foreign state defendant, different results

12(b)(1), a motion to dismiss for failure to state a claim for relief, FED. R. CIV. P. 12(b)(6), or a motion for summary judgment, FED. R. CIV. P. 56. Indeed, it is worth noting that the courts that have addressed sovereign immunity claims under the Act have not appeared to be concerned about what procedural device was used for raising the issue. Litigants have used a range of methods and, appropriately, the focus has been on the substance of the claim itself, not the form in which it was raised. See cases cited in note 159 supra.

169. The early resolution of sovereign immunity questions may not always be possible as, for example, when resolution would require a serious inquiry into the merits. In that event, immunity may be postponed. The major countervailing consideration is whether the delay in raising the issue has unduly prejudiced the plaintiff.

170. FED. R. Giv. P. 12(g); see 5 C. WRight \& A. Miller, supra note 14, $\$$ 1384-1389.

171. State systems using special appearances as the means of raising jurisdiction questions often provide that the defendant must put forward that objection as the first act taken in the action and cannot join other defenses for preliminary consideration at the same time or waiver will occur. See RESTATEMENT (SECOND) OF JUDGMENTS $\$ 13$, comment b (Tent. Draft No. 5, 1978); Thode, In Personam Jurisdiction; Article 2031B, The Texas "Long Arm" Jurisdiclion Statute; And the Appearance to Challenge Juristiction in Texas and Elsewhere, 42 TEx. L. REv. 279 (1964). Applying these rules, the failure to raise sovereign immunity at the outset and alone could be deemed an implicit waiver. 
may obtain than if the enforcement proceeding were to take place in the United States.

Within this country, constitutional and statutory requirements provide that judgments rendered in one court system which are enforced in another judicial system must be given the same faith and credit to which they would be entitled in the state rendering judgment. ${ }^{172}$ The only exceptions to this rule involve objections to default judgments, because of the general preference for decisions on the merits. ${ }^{173}$ Otherwise, once the defendant has appeared in one court system and litigated there, judicial economy demands that any judgment that is entered be final and binding. ${ }^{174}$

Applying this approach to sovereign immunity, a foreign state should be successful in collaterally attacking a United States judgment on sovereign immunity grounds only when a default judgment is involved. ${ }^{175}$ Immunity, like jurisdiction, presents an important issue that courts should not foreclose without some scrutiny. But if the state raised the issue in the first court and lost, there is no reason to relitigate the question. And if the state litigated the merits of the action, but failed to raise its immunity claim, its interjection of the issue on collateral attack would be untimely and could prejudice the judgment winner severely; in that situation, the court should rule that the defendant impliedly waived its right to claim immunity by its conduct in the first proceeding. ${ }^{176}$

International enforcement of judgments against foreign sovereigns is harder to predict. Enforcement is a matter of comity, not a product of constitutional compulsion. ${ }^{177}$ Thus, in deciding whether

172. See U.S. ConST. art. IV, § 1; 28 U.S.C. $\$ 1738$ (1976).

173. See Schwab v. Bullock's, Inc., 508 F.2d 353 (9th Cir. 1974); Restatement (SECOND) OF JudGMENTs $\S 15$ (Tent. Draft No. 5, 1978).

174. See Durfee v. Duke, 375 U.S. 106 (1963); Baldwin v. Iowa State Traveling Men's Ass'n, 283 U.S. 522 (1931).

175. There is authority authorizing the United States to make a collateral attack on a judgment entered after a full trial on the merits on grounds of sovereign immunity. See United States v. United States Fidelity \& Guar. Co., 309 U.S. 506 (1940). Because the Act is designed to provide similar treatment for foreign governments and the United States, one could argue that the Act permits foreign governments to make a collateral attack even when a default judgment is not involved. But this argument is ill-conceived. The rationale supporting the right of the United States to attack the judgment was that a single attorney from the Justice Department had no authority to acquiesce in a suit on behalf of the government. In actions under the Act, foreign government officials with greater authority will be apprised of the action because of the Act's service requirements, see notes 68-84 supra and accompanying text, and it is not unreasonable to interpret the defendant's failure to raise immunity at any stage in the first proceeding as a conscious decision to waive it.

176. See notes 164-66 supra and accompanying text.

177. See A. EhrenzWeig, supra note $63, \S 46$; Restatement (Second) of Conflict 
to enforce an American judgment, a foreign court may take into account the differences between the two legal systems and whether it would violate the foreign court's public policy to enforce the judgment. ${ }^{178}$ In that case, a collateral attack on immunity grounds that would fail in the United States might be successful elsewhere. ${ }^{179}$

In summary, the underlying policies of the Act, coupled with the apparent intent of Congress, suggest that the foreign state must bear the burden of raising any sovereign immunity claims and must discharge that burden at an early stage in the proceeding-preferably before or in the responsive pleading. Further, courts should not apply technical rules of pleading or pretrial motions to avoid considering the immunity issue on its merits. It should not matter what procedure the defendant uses to interject immunity into the action as long as the introduction of the issue is timely and whatever delay has occurred does not prejudice the opposing party. In keeping with this flexible approach, a foreign state defendant may attack a default judgment on grounds of sovereign immunity, but may not make a collateral attack in United States courts after a trial on the merits.

\section{Proving sovereign immunity.}

Congress apparently conceived of the proof of sovereign immunity as a process of shifting burdens between the parties. ${ }^{180}$ But an analysis of the Act and its legislative history merely identifies who bears these burdens; it does not explain how parties may satisfy them.

Although the Act's shifting of the burden of proof may seem awkward or complex, there is much to commend it. Establishing immunity most often will depend on a factual inquiry, and the facts necessary to meet the standard are most easily accessible to, if not

OF LAws $\$ 98$ (1971); see also Schibsby v. Westenholz, [1870] 6 Q.B. 155 (refusing to enforce in an English court the judgment of a foreign court that did not have proper jurisdiction over the defendant).

178. Although the principle of restrictive sovereign immunity is commonly applied by other countries, the Act's characterization of the situations which fall within that principle is not recognized as widely. See Restatement of Foreign Relations LaW OF THE UNITED States (ReviSed) $\S 451$, at 179 (Tent. Draft No. 2, 1981); see also State Immunity Act, 1978, c. 33, §§ 1-11, reprinted in 17 INTERnational LEgal Materials 1123 (1978); European Convention on State Immunity, May 16, 1972, art. 1-15, Europ. T.S. No. 74. Thus, to the extent that these standards are markedly different from those of the United States, public policy may be invoked to avoid the judgment on the ground that it violates the concept of immunity adhered to in the enforcement forum.

179. In the United States, arguments of public policy will not succeed in avoiding the full faith and credit requirement. See Fauntleroy v. Lum, 210 U.S. 230 (1908); note 172 supra and accompanying text.

180. See note 160 supra and accompanying text. 
within the exclusive control of, the foreign state. ${ }^{181}$ Further, since the question arises at a preliminary stage of the litigation, there need not be a full evidentiary hearing; affidavits of foreign state officials should suffice. ${ }^{182}$

Once the defendant shows that it fits within the category of immune government entities, the court must determine whether it has engaged in the type of activity that deprives it of immunity, or has waived its right to claim immunity. ${ }^{183}$ This inquiry usually will depend on the plaintiff's substantive claim for relief. For example, a court will find an exception to immunity if the plaintiff claims a right to relief because the defendant took its property in violation of international law. ${ }^{184}$ Thus, the plaintiff should bear the burden of establishing that an aspect of the defendant's conduct requires an exception to immunity. This burden is not an onerous one; plaintiff's allegations of facts supporting the invocation of a given exception should meet it. ${ }^{185}$

But to the extent that an exception to immunity depends on a more detailed inquiry, the burden of demonstrating that the exception does not apply should be on the defendant, who has access to the facts. Meeting this burden requires the defendant to present evidence supporting its version of the facts. ${ }^{186}$ In this way, the party best able to provide the information necessary for the court to evaluate the question of sovereign immunity bears the burden of doing so. This is a proven and useful guide for allocation and carries here the additional imprimatur of congressional sanction.

\section{Right to Jury Trial}

Section 1330 limits the subject matter jurisdiction of the federal

181. For example, if the defendant is an agency or instrumentality of a foreign state, it may claim immunity only if (1) it is a separate legal person, (2) it is an organ of a foreign state or the state maintains a major or controlling ownership interest in the entity, and (3) it is not otherwise a citizen of the United States or created under the laws of any third country. See 28 U.S.C. $\$ 1603(b)$ (1976). If the defendant, though controlled by a foreign state, is incorporated under the laws of one of the fifty states, it is to be treated like any other American corporation and may not claim the special benefits and protections of a foreign state. See HOUSE REPORT, supra note 18, at 15, reprinted in [1976] 5 U.S. CODE CONG. \& AD. NEWS $6604,6614$.

182. See, e.g., Sugarman v. Aeromexico, Inc., 626 F.2d 270 (3d Cir. 1980).

183. See 28 U.S.C. § $1605(a)(1)$ (1976).

184. See id. § $1605(\mathrm{a})(3)$.

185. Cf. Jet Line Services, Inc. v. M/V Marsa El Hariga, 462 F. Supp. 1165, 1171-72

(D. Md. 1978) (placing initial burden of coming forward on defendant in attachment action).

186. See, e.g. , Behring Int'l, Inc. v. Imperial Iranian Air Force, 475 F. Supp. 396, 407-08 (D.N.J. 1979). 
courts in suits brought under the Act to nonjury cases, ${ }^{187}$ treating these actions similarly to actions brought against the United States. ${ }^{188}$ This provision raises two related questions. The first is whether a plaintiff may demand a jury trial when subject matter jurisdiction is founded in statutes other than the Act. ${ }^{189}$ The second is whether a legislative policy against jury trials can be enforced consistently with the seventh amendment. ${ }^{190}$

The first question must be answered in the negative: The Act's stand against jury trials should preclude jury trials in all actions against foreign governments. A variety of arguments have been made against this conclusion. ${ }^{191}$ One is that the language that forbids jury trial is present only in the jurisdictional section of the Act, ${ }^{192}$ not in the sections substantively defining sovereign immunity that would apply to actions brought under any source of jurisdiction. This should be considered as a legislative oversight, however-one that resulted from the Act's pervasive confusion of procedural and substantive requirements. Although Congress did not consider fully the constitutional ramifications of its nonjury policy, it is quite clear that it did consider the advantages and disadvantages of jury trials and favored abolishing them. A strong concern was expressed that uniformity in decisions should be fostered in suits against foreign

187. See 28 U.S.C. $\$ \S 1330(a), 1441$ (d) (1976).

188. Id. $\S 2402$. That there is no right to a jury trial in actions brought against the United States was recently reaffirmed in Lehman v. Nakshian, 101 S. Ct. 2698 (1981).

189. As, for example, when jurisdiction may be claimed on the basis of diversity of citizenship. See 28 U.S.C. $\$ 1332$ (1976). For a discussion of whether a court may base subject matter jurisdiction in an action against a foreign sovereign on a statute other than the Act, see notes 39-47 supra and accompanying text.

190. Some courts have treated jury trial demands by asking whether Congress intended the Act's subject matter provisions to be the exclusive means of obtaining federal subject matter jurisdiction in suits against foreign sovereigns. Sec, e.g. , Williams v. Shipping Corp. of India, 489 F. Supp. 526 (E.D. Va. 1980), affd, 653 F.2d 875 (4th Cir. 1981); Lonon v. Companhia de Navegacao Lloyd Basileiro, 85 F.R.D. 71 (E.D. Pa. 1979). But this approach confuses jurisdiction with jury trial concerns and fails to consider important policy and constitutional issues. See notes 193-94 infra and accompanying text.

191. See, e.g., Rex v. Cia. Pervana de Vapores, S.A., 493 F. Supp. 459 (E.D. Pa. 1980) (arguing that since Congress allows actions to be filed in state court, plaintiffs will bring actions outside of the federal court system to avoid the jury prohibition). But this argument fails to recognize that if Congress intended to bar jury trials in actions against foreign sovereigns, then state courts would be obliged to honor that decision in actions filed there. Cf. Dice v. Akron, C. \& Y. R.R., 342 U.S. 359 (1952) (statutory provision for jury trial not "local rule of court," hence binding on state courts). In general, courts have refused to be bound by the Act's legislative history and have noted that the Act on its face does not require such a broad construction. See, e.g., Lonon v. Companhia de Navegacao Lloyd Basileiro, 85 F.R.D. 71 (E.D. Pa. 1979); Icenogle v. Olympic Airways, S.A., 82 F.R.D. 36, 40 (D.D.C. 1979).

192. 28 U.S.C. $\S 1330$ (a) (1976). 
governments and that uniformity could be achieved best by judge trials. ${ }^{193}$ Moreover, suits against foreign sovereigns, with all their potential for creating international friction, may require that some protections be afforded to avoid at least the needless friction that might arise because of a perceived aberrant verdict rendered by a jury. ${ }^{194}$

The seventh amendment issue is less complicated. The Supreme Court has held that the Constitution guarantees a civil jury trial whenever the nature of the relief sought is such that it would have warranted a jury trial if brought at common law. ${ }^{195}$ But jury trial was not available at common law in any suit against a foreign sovereign because immunity precluded any action from being brought. ${ }^{196}$ Without a common law analogue to the modern action under the Act, the seventh amendment should not preserve the jury trial rights of modern-day plaintiffs suing governmental entities: One cannot preserve what never existed. ${ }^{197}$

193. See HOUSE REPORT, supra note 18 , at 13 , reprinted in [1976] 5 U.S. CODE CONG. \& AD. NEws 6604, 6611-12. Allowing a jury trial simply because the plaintiff is able to claim jurisdiction under some additional statute could seriously undercut that decision. As Judge Friendly argued in Ruggiero v. Compania Peruana de Vapores "Inca Capac Yupanqui," 639 F.2d 872, 876 (2d Cir. 1981), "The courts must learn to accept that, in place of the familiar dichotomy of federal question and diversity jurisdiction, the Immunities Act has created a tripartite division-federal question cases, diversity cases and actions against foreign states. If a case falls within the third division, there is to be no jury trial even if it might also come within one of the other two." See also Restatement OF Foreign RELATIONS Law OF THE United States (REviSED) § 457, at 212 (Tent. Draft No. 2, 1981).

Even though the Act precludes jury trials in suits against foreign sovereigns, a jury trial is still permissible for related claims against any private, nongovernmental defendants that are joined in the suit. In such cases the judge may determine the facts concerning the state, and the jury concerning the other defendants. See Outboard Marine Corp. v. Pezetel, 461 F. Supp. 384, 396 (D. Del. 1978). But of. Goar v. Companhia Peruana de Vapores, 510 F. Supp. 737 (E.D. La. 1981) (denying any jury trial in action against foreign sovereign vessel owner and domestic insurer due to possible conflict between factfinders).

194. That foreign governments are subject to jury trial when they sue as plaintiffs in United States courts proves nothing to the contrary, for so is the United States itself when suing in a proprietary capacity, such as in an action for trespass on government-owned lands when title is involved. See United States v. Williams, 441 F.2d 637 (5th Cir. 1971). Moreover, the state, by filing suit and thereby invoking the protection of the American courts, must submit itself to all the procedural trappings of American court litigation. It can claim no right to special treatment. Thus, while it is perfectly legitimate to construe a statute to avoid constitutional problems, in this instance the nonjury trial policy seems clear.

195. See Pernell v. Southall Realty, 416 U.S. 363 (1974); Curtis v. Loether, 415 U.S. 189 (1974).

196. See Galloway v. United States, 319 U.S. 372, 388 (1943); McElrath v. United States, 102 U.S. 426 (1880).

197. Some litigants have argued that suits brought under the Act represent situations in which the United States has decided to authorize suits against foreign governments, regardless of their consent, and thus the right to jury trial should be tested by the underlying claim for relief, not by the character of the parties. See Rex v. Cia. Pervana de Vapores, S.A., 493 F. 
The principal argument against this conclusion involves suits against the agencies or instrumentalities of foreign states, rather than the states themselves. Historically, the concept of foreign sovereign immunity was a limited one because government activities were limited in scope. Only within modern times have governments delegated authority to numerous agencies with independent powers to act, or controlled major portions of their nations' economies. Congress took these changes into account in the Act and defined "foreign state" to include many of these entities. ${ }^{198}$ Thus, it is arguable that modern governmental agencies that do not fit within the traditional concept of a foreign state should be treated as private parties for jury trial purposes. ${ }^{199}$ Then, if the underlying claim were legal rather than equitable, the plaintiff would be able to assert a legitimate seventh amendment right to a jury trial, regardless of the intent of Congress.

But this argument does not adequately recognize the power of Congress to create statutory causes of action. In other areas in which the courts have ruled that a jury trial was required, Congress had been silent on the question, so that a court could find no basis for a legislative decision that a jury trial would be inadequate or dysfunctional. ${ }^{200}$ But when, as here, there is no historical counterpart to a particular action, and when Congress has clearly expressed a preference against jury trials that is a legitimate policy decision, the seventh amendment does not mandate otherwise. ${ }^{201}$

Supp. 459, 465 (E.D. Pa. 1980). Although some seventh amendment decisions appear to expand the constitutional jury trial guarantee to whenever the underlying nature of the issue to be resolved is legal in character, these rulings should not be read too broadly. In each case, the Court considered either whether Congress could create a statutory action simply by indicating a preference for nonjury trial, or whether the availability of modern procedural devices would allow a jury trial when historically comparable actions were tried in equity. See Ross v. Bernhard, 396 U.S. 531 (1970); Dairy Queen, Inc. v. Wood, 369 U.S. 469 (1962); Beacon Theatres, Inc. v. Westover, 359 U.S. 500 (1959). In no case did the Court rule on an action that could not be brought in the common law courts regardless of the procedures available. See Williams v. Shipping Corp. of India, 653 F.2d 875 (4th Cir. 1981); Ruggiero v. Compania Peruana de Vapores "Inca Capac Yupanqui," 639 F.2d 872, 880-81 (2d Cir. 1981); see also Kane, Civil Jury Trial: The Case for Reasoned Iconoclasm, 28 Hastings L.J. 1, 12 (1976).

198. See 28 U.S.C. § 1603(a)-(b) (1976). 1980).

199. See Rex v. Cia. Pervana de Vapores, S.A., 493 F. Supp. 459, 466 n.6 (E.D. Pa.

200. See Pernell v. Southall Realty, 416 U.S. 363 (1974); Curtis v. Loether, 415 U.S. 189 (1974).

201. See Atlas Roofing Co. v. Occupational Safety \& Health Review Comm'n, 430 U.S. 442 (1977). Congress's treatment of instrumentalities of the United States government provides further support for the conclusion that the seventh amendment does not mandate a jury trial in actions against the instrumentalities of foreign sovereigns. No doubt much of the 


\section{CONCLUSION}

The ambiguous drafting of the Foreign Sovereign Immunities Act has led to numerous inconsistencies and conflicts among the courts in recent decisions. This article has considered, in sequence, the most important procedural issues a prospective plaintiff under the Act will encounter.

Many of these problems result from the confusing mixture of procedural and substantive matters in the structure of the Act. The recognition of these concerns, combined with a sensitivity to the purposes of the Act and its intended interaction with other laws, provides an analytical approach that can help to resolve the problems the Act presents. This article has demonstrated how that approach can be applied to develop a consistent and fair interpretation of the Act's provisions. This analysis ultimately will provide plaintiffs and defendants with a predictable legal structure to be applied in all actions against foreign sovereigns.

impetus for the Act came from concern about the state "instrumentalities" that perform functions which in this nation are carried on by private enterprises enjoying no sovereign immunity. In the United States, Congress waived any immunity that government instrumentalities engaged in commercial activity, such as the Tennessee Valley Authority and the Commodity Credit Corporation, might have enjoyed, by including standard sue-and-suability clauses in their charters. See 16 U.S.C. $\$ 831 \mathrm{c}(\mathrm{b})$ (1976) (Tennessee Valley Authority); 15 U.S.C. $\S 714 \mathrm{~b}(\mathrm{c})$ (1976) (Commodity Credit Corporation). The TVA charter is silent on jury trial, and the Commodity Credit Corporation charter precludes jury trial in suits "against" the corporation. Id. In practice, no jury trial is allowed, regardless of the nature of the underlying claim for relief, unless the federal government sues in the guise of its controlled instrumentality. See Cargill, Inc. v. Commodity Credit Corp., 275 F.2d 745 (2d Cir. 1960); see also United States ex rel. TVA v. Undivided One-Seventh Fee Simple Interest in a Tract of Land Containing 0.43 Acre, More or Less, in Franklin County, Tennessee, 304 F. Supp. 1241 (E.D. Tenn. 1969). Admittedly, many foreign nations are more disposed than we are to employ instrumentalities. Nonetheless, the Act is at least consistent in treating foreign government instrumentalities the same as domestic ones. 
HeinOnline -- 34 Stan. L. Rev. 426 1981-1982 